\title{
Between the Protection and Humanity: The Implementation of Ultimum Remedium Principle in Immigration Cases
}

\author{
Alamsyah Bahari \\ ALBI Law Office and Partners, Jakarta, Indonesia \\ Corresponding Author: A. Bahari, email: alamsyahbaharilaw@gmail.com
}

\begin{abstract}
Global population mobility has an impact on legal aspects, especially in the case of immigration matters. Increased mobility of migration flows also has various impacts, not only positive but also negative impacts, for example changing the pattern of crime from domestic crime to transnational crime, from individual crime to group crime, from unorganized crime to organized (organized crime). Various administrative and criminal sanctions are applied to many immigration offenders. This paper examines in depth the application of the principle of ultimum remidium in criminal law for criminal acts of immigration in Indonesia. This study aims to find out and understand how the ultimum remedium principle is applied in Law Number 6 of 2011 concerning Immigration. In addition, this study also aims to find out and understand the factors that cause Immigration Officers to use Administrative Sanction Acts or Criminal sanctions in Law Number 6 of 2011 concerning Immigration, as well as to know and understand Immigration law enforcement practices in Law Number 6 of 2011 concerning Immigration in Indonesia. This research has confirmed and underlined that the application of administrative sanctions in the form of deportation and fines will complete the immigration legal process quickly, simply and at a modest cost and applying relatively high fines can benefit the country, hence the benchmarks for the principle of ultimum remedium can be applied in the Law Law No. 6 of 2011 concerning Immigration.
\end{abstract}

Keywords: Immigration Crimes, Ultimum Remedium, Criminal Law, Protection, Human Rights

\section{How to cite:}

Bahari, A. (2020). Between the Protection and Humanity: The Implementation of Ultimum Remedium Principle in Immigration Cases. Indonesian Journal of Advocacy and Legal Services, 2(2), 123-198. https://doi.org/10.15294/ijals.v2i2.38134 


\section{A. Introduction}

The 1945 Constitution of Indonesia clearly states that the Indonesian State is based on law (rechstaat), not based on mere power (machtstaat), this means that the State of the Republic of Indonesia is a democratic state based on Pancasila and the Republic of Indonesia Constitution of 1945, upholds human rights and guarantees all the rights of citizens whose position is equal before the law. ${ }^{1}$ Regardless as an Indonesian citizen or foreign citizen if commited a crime and violation it will be processed legally.

Law is an interesting theme to discuss, this is because the law is basically closely related to the development of the life of every human being who lives on earth. With the destruction of a law, then from there it can be seen the failure of a nation in creating law, even this can also show the decline of a nation if it experiences a setback in ethics and behavior. Indonesia is now experiencing a massive legal problem, the use of law that has no conscience and the problem of marginalization of a group of people by law has often occurred in this country. ${ }^{2}$

The impact of the globalization era has affected the economic system of the Republic of Indonesia and to anticipate it, it is necessary to amend regulations in the fields of economy, industry, trade, transportation, labor, as well as regulations in the field of traffic of people and goods. These changes are needed to increase the intensity of relations between the Republic of Indonesia and the international world which has a very large impact on the implementation of the functions and duties of Immigration. ${ }^{3}$

A long history of world immigration also occurs in the United States and Mexico, in addition to the problem of terrorism, the United States also has a classic problem around the border region with Mexico. For years the United States has paid attention to the problem of transnational activities from Mexico which are mostly illegal immigrants. Problems arising from the entry of illegal immigrants from Mexico include violence between individuals and communities, people, and drug smuggling. The issue was the campaign material of President Donald Trump before he took up the presidency in 2016. Traditional issues that only discuss state security from the military aspect

1 Armili Anwar, "Perbedaan Penahanan Yang Dilakukan Oleh Pihak Kepolisian Dengan Penahanan Yang Dilakukan Oleh Pihak Imigrasi," Thesis, Universitas Indonesia, 1984, pp. 1-10

2 Esmi Warassih Pujirahayu, Pemikiran Hukum Spritual Pluralistik, Yogyakarta, Thafa Media, 2017, pp.1-6.

3 Republic of Indonesia, Law Number 6 of 2011 concerning Immigration (hereinafter as Immigration Law). 
have been extended to several non-traditional security issues, including terrorism, the global financial crisis, HIV/AIDS, global environmental damage, poverty, human rights, and refugees. ${ }^{4}$

Trump said that the main cause of the many terrorist incidents, one of which was the mass shootings in Orlando, was because the United States allowed immigrants with radical Islamic views to enter the United States. Therefore, Trump said that the plan to ban immigration from countries with a history of terrorism will be his priority. He will use the president's executive rights to protect the American people. The second threat that is also crucial for the security of the people of the United States is the presence of illegal Mexican immigrants. Donald Trump said that immigrants from Mexico were problematic people, and brought problems to the United States, such as drug smugglers, criminals, rapists, even though some of them were good people. ${ }^{5}$

On July 26, 2015, Trump said that his immigration policy plan would begin by deporting " $b a d$ " irregular immigrants, returning them to where they came from. On January 25, 2017 Trump issued an executive order "Border Security and Immigration Enforcement Improvements" which mainly contained orders to secure the southern border of the United States through the immediate construction of walls along the border, which were monitored and supported by adequate personnel, with the aim of blocking the entry of illegal immigration, human trafficking and illegal drugs, and acts of terrorism. ${ }^{6}$

Then on January 27, 2017, Trump issued an order to protect the nation from foreign terrorists to enter the US by banning immigration from Iran, Iraq, Libya, Somalia, Sudan, Syria and Yemen for 90 days, or "Executive Order: Protecting the Nation From Foreign Terrorist Entry Into The United States". However, on March 6, 2017, the executive order "Protecting the Nation from Foreign Terrorist Entry into The United States".7

Trump's policy to build a border wall between the United States and Mexico has become an international public spotlight. The construction of a wall on the border is another controversy after Trump's policy which

4 BBC, "Donald Trump: Mexico will pay for wall, '100\%"'. BBC-news. Retrieved from http://www.bbc.com/news/election-us2016-37241284.

5 TIME, "Here's Donald Trump's Presidential Announcement Speech". Time.com. Retrieved from http://time.com/3923128/donald-trumpannouncement-speech/

6 Rebecca Shabad, "No, Trump's victory was not the biggest Electoral College win since Reagan". Retrieved from http://www.cbsnews.com/news/no-trumpsvictory-was-not-thebiggest-electoralcollege-win-since-reagan/

7 The White House, "Executive Order Protecting the Nation from Foreign Terrorist Entry into The United States". Retrieved from https://www.whitehouse.gov/thepressoffice/2017/01/27/executive-orderprotecting-nation-foreign-terrorist-entryunitedstates. 


\section{A. Bahari}

restricted immigrants from several Muslim countries came to the United States. Based on the initial plan, the wall will be built along 200 miles with a height of 12.2 meters. On January 25, 2017 Trump signed a presidential decree on building the border wall. The total estimated cost to be incurred in the construction of the wall is 11.84 million United States dollars. ${ }^{8}$

The wall construction is a continuation of the immigration restriction project campaigned by Trump. In addition to immigrants, the construction of the wall is also intended to limit the smuggling of illegal goods that enter the United States from Mexico. Even so, the US border already has a parapet. However, the height is only around 5.5 meters. The construction of this border will place the character of the United States-Mexico border in an alienated condition. Just like what happened in West and East Germany with the Berlin Wall as a dividing between the two countries. Strict control of foreign nationals who enter national borders is one of the characteristics of alienated border characters. If it refers to the national security perspective, this is very possible because state sovereignty is something that must be fulfilled. So that its integrity as a country must be maintained from all forms of threats, especially from the threat of illegal immigration and other negative impacts caused. 9

Historically although the Indonesian state has not ratified the 1951 Refugee Convention, Indonesian humanitarian reasons have begun to protect refugees since refugees from Vietnam, known as the Vietnamese Boat People, which occurred between 1975-1980 where thousands of asylum seekers were placed on Galang Island before they were returned to the country the origin. ${ }^{10}$

The problem of refugees continues to occur until now the country of Indonesia is a transit point for asylum seekers, for example Afghan citizens, one of the reasons why Afghan nationals chose Indonesia as a transit country to seek asylum, because Indonesia is a Muslim country that is safe for them.

Asylum seekers in Indonesia are divided into 2 (two) types, there are immigrants who are financially able and immigrants who are financially unable. Of course, immigrants who are financially capable can finance their own lives in Indonesia and live in luxury apartments. Dissecting with

8 Pitoko R A, "Donald Trump Bangun Tembok Perbatasan AS-Meksiko". Kompas, from http://properti.kompas.com/read/2017/01/27/070000521/donald.trump.bangun.tembok.pe rbatasan.as-meksiko

9 National Geographic Indonesia. "Dinding Perbatasan Amerika Serikat dan Meksiko Sudah Ada, dan Kami Mengunjunginya", retrieved from http://nationalgeographic.co.id/berita/2017/01/dinding-perbatasan-amerika-serikatdanmeksiko-sudah-ada-dan-kamimengunjunginya.

10 Rosmawati, "Perlidungan Terhadap Pengungsi/Pencari Suaka di Indonesia Menurut Convensi 1951", Kanun Jurnal Ilmu Hukum Vol. No.67, XVII, December, 2015, pp. 2-6. 
immigrants who are financially incapable because for housing accommodation and the cost of daily living depends on the helping hand of international organizations such as the International Organization for Migration (IOM) and United The United Nations High Commissioner for Refugees (UNHCR). ${ }^{11}$

The history of immigration politics during the reign of the Dutch East Indies, Immigration carried out an open-door politics (opendeur politiek) for general reasons known ${ }^{12}$ :

a. To attract foreign capital and influence to the maximum extent of Indonesia with the hope that the Indonesian nation itself could not move at all because everything was encompassed and suppressed by this influence;

b. Thus, the Indonesian people certainly remained colonized

c. Hope is also shown, that if there is an attack from Indonesia on the outside, it is not only the Dutch government that defends Indonesia, because other countries that have put their capital in Indonesia certainly have an interest and will help Indonesia;

d. On the other hand, foreign capital requires cheaper energy, more profitable capital earlier.

Even so foreign companies still need the arrival of workers from abroad with the intention of being made rivals of domestic workers, so that labor costs can be further suppressed. With the entry of foreigners into Indonesia, the Immigration Act is regulated.

After the Indonesian State became independent, immigration politics were harmonized with State politics for the safety and welfare of the nation which made Indonesian immigration politics use a selective policy, meaning immigration officials must be careful of the documents of foreigners entering the Indonesian State. This is confirmed in Article 8 paragraph (1) and (2) of Law Number 6 of 2011 concerning Immigration which states:

(1) Every person entering or leaving Indonesian territory must have a valid and valid Travel Document

(2) Every foreigner entering the Territory of Indonesia is required to have a valid and valid visa, unless otherwise specified under this Law and international treaties.

The enactment of Presidential Regulation No. 21 of 2016 concerning Visa Free Visit, making immigration law politics currently re-open politics

11 Result of Interview with Jaya Saputra, SH.MH, As Head of Sub Directorate of Indonesian Immigration Investigation

12 Andi Hamzah, Delik-Delik Tersebar Di Luar KUHP, Jakarta, PT Pradnya Paramita, 1995, p. 76. 


\section{A. Bahari}

open door (opendeur politiek), this is a legal consequence of the State of Indonesia which is a member of the Association of Southest Asian Nation (ASEAN) which resulted in an agreement agreements in various fields including economics and law. The development of cooperation between ASEAN countries also developed until the formation of the Asean Economic Community (AEC) with one of the objectives being ASEAN as a single market and international production base (single market and production base) with one of its elements namely visa-free policy. ${ }^{13}$

The development of increasing world population mobility has had a variety of impacts, both which are beneficial and detrimental to the interests and lives of the nation and the State of Indonesia, such as the existence of the Asean Economic Community (AEC) not only opening up the flow of goods or services trade, but also the professional labor market, such as doctors, lawyers, and accountants are guaranteed by Presidential Regulation No. 21 of 2016 concerning Visa Free Visit, it is stated that foreign nationals of certain countries to enter the Territory of Indonesia are exempt from the obligation to have a visitor visa by taking into account the principle of reciprocity ) and benefits. ${ }^{14}$

An increase in migration flows between countries can have positive and negative impacts. Positive impacts include such as the modernization of society and encouraging economic growth for countries that are able to make the best use of migration out of their territory. The negative impact of migration flows is that when migration flows with legal schemes become very difficult for migrants to choose from, immigration efforts with illegal patterns emerge. This situation encourages the increasing development of crime both in quantity and quality. For example, from the aspect of the quality of domestic crime into transnational crime (transnastional crime), from individual crime to group crime, from organized crime to organized crime. ${ }^{15}$ The relation is to maximize the positive impacts and minimize the negative impacts of the flow of migration, one of the implementing elements in overseeing the traffic of people outside the country is the immigration institution.

13 Inanda Agustina, "Politik Hukum Imigrasi Nasional Pasca Terbentuknya Masyarakat Ekonomi ASEAN", Jurnal Pena Justisia: Media Komunikasi dan Kajian Hukum, Vol. 17 No. 2, pp 60-61.

14 Okky Chahyo Nugroho, Implementasi Projusticia Terhadap Pengawasan Orang Asing, Jakarta, Badan Penelitian dan Pengembangan Hukum dan HAM, 2016, pp. 2-4.

15 Imam Santoso, Perspektif Imigrasi Dalam United Nation Convention Against Transnational Organized Crime, Jakarta, Perum Percetakan Negara, 2007, p. 2. 
Based on data from the National Statistics Agency, Tourists entering the State of Indonesia have increased every year in 2017 totaling 14. 039,799 (fourteen million thirtynine thousand seven hundred ninetynine) and 2018 totaling 15. 806,191 (fifteen million eight hundred six thousand one hundred ninetyone) people, ${ }^{16}$ from the available data it can be concluded that every year foreigners entering the Indonesian Territory experience a significant increase. Of course, this encourages the war of immigration to be more careful in enforcing immigration law.

The State of Indonesia is currently facing a quite serious problem, besides the State of Indonesia which is currently being intensively introducing national citizenship to foreign countries to invite tourists to enter Indonesia for the sake of improving the people's economy. On the one hand, the Indonesian State must also be careful of illegal immigrants entering Indonesia, either by reason of work, seeking asylum or other reasons, because the Indonesian State currently still has a high number of unemployment, in contrast to the State of Malaysia, where refugees in Malaysia can work in plantation areas. Although the Indonesian State has not ratified the Convention on Refugees, Humanitarian reasons based on the Pancasila are the basis of the Indonesian State to help protect illegal immigrants seeking asylum in Indonesia. Another problem that arises is whether the refugees will stay in Indonesia forever without a definite time limit.

Asylum seekers thronged Jakarta precisely on Jalan Kebon Sirih, to seek asylum, the Jakarta administration decided to move asylum seekers who lived on the Jalan Kebon Sirih sidewalk, Central Jakarta to the ex West Jakarta Kodim land. The DKI Jakarta Provincial Government plans to set up tents for asylum seekers' homes with tents, toilets and water facilities. The Regional Government has the authority to regulate the United Nations High Commissioner for Refugees (UNHCR) based on Perpres 126 of 2016 concerning Handling Overseas Refugees, where local governments can assist UNHCR in the name of humanity. Chairman of DKI Jakarta DPRD Prasetyo Edi Marsudi revealed based on a sense of humanity finally the DKI Provincial Government and the DPRD decided to relocate them today. "Because if there is anything, this is not the business of the Regional Government. But because it is consistent with the humanitarian element. Prasetyo claimed that he could not help their demands with UNHCR asking to be transferred to

16 BPS, "Jumlah Orang Asing Yang Masuk Negara Indonesia", retrieved from https://www.bps.go.id/subject/16/pariwisata.html\#subjekViewTab1. 


\section{A. Bahari}

another country. The issue of requesting political asylum from UNHCR is their concern with UNHCR. ${ }^{17}$

The refugees who will seek asylum will be placed first in the Temporary Shelter, and Accommodation (Community House). In 2018 the number of asylum seekers in the Shelter amounted to 1,064 (one thousand sixtyfour) and the number of asylum seekers in accommodation (Community House) amounted to 7,166 (to the thousand one hundred sixtysix). Accommodation (Community House) is spread in several provinces in Indonesia. 18

The definition of immigration can be found in Article 1 of Law Number 6 of 2011 concerning Immigration which states that immigration is a matter of the traffic of people entering or leaving Indonesian Territory and its supervision in order to maintain the upholding of the country's sovereignty. ${ }^{19}$

With the increasing traffic flow of people and relations between countries, various immigration arrangements are needed for the implementation of crossings of people which is a combination of national and international aspects. However, looking at the universality of the function and role of immigration, the emphasis remains on the sovereignty aspects of each country. ${ }^{20}$

Immigration officials have a function called the Immigration Trifunction, the first of which is the community service function, the function of the security forces, and the legal enforcement function. ${ }^{21}$ Immigration has the authority to supervise foreigners not only when they enter, but also while they are in Indonesian territory, including their activities. Immigration control includes enforcement of immigration law, both administrative and immigration. ${ }^{22}$

Immigration Law if it is related to the parent's legal science, Immigration law is a part of state law, especially branches of administrative law (administriefrecht). ${ }^{23}$ This can be seen from the Immigration function

17 Gregorius Aryodamar P, "Pencari Suaka di Kebon Sirih Dipindahkan ke Kalideres, Ini Alasannya", from https://today.line.me/ID/pc/article/G1PpNy?utm_source=washare

18 Directorate of Immigration, "Data on Asylum Seekers and Refugees throughout Indonesia per September 2018 [Data Pencari Suaka dan Pengungsi di Seluruh Indonesia Periode September 2018]", p.1

19 Immigration Law

20 Imam Santoso, Op.Cit., pp. 2-5.

21 Amalia Diamantina, Amiek Soemarni, Astrid Ditha F.A, "Pelaksanaan Deportasi Orang Asing di Indonesia Berdasarkan Undang-Undang Nomor 6 Tahun 2011 Tentang Keimigrasian (Studi Kasus Kantor Imigrasi Jakarta Timur)", Diponegoro Law Review Vol. 5, No. 2, 2016, pp.13-15; Muhammad Alvi Syahrin, "The Immigration Crime and Policy: Implementation of PPNS Authorities on Investigation". JILS (Journal of Indonesian Legal Studies), Vol. 3 No. 2, 2018, pp. 175-194.

22 Immigration Law 
which is carried out based on the functions of government administrators or the State administration (bestuur) and public service (publiek dienst), not the function of forming a law (wetgever) and not also the function of justice (rechtspraak). ${ }^{24}$

In addition to the regulatory function that contains administrative legal aspects, immigration law also has the function of immigration polisional law enforcement. This function includes things such as the refusal of foreigners to enter Indonesian territory because they do not meet the requirements, imposition of administrative immigration sanctions, and cancellation of residence permits. In addition to administrative sanctions immigration can also be subject to administrative sanctions such as administrative fines and criminal sanctions. It must be distinguished that the fine herein is administrative in nature which is declared by an administrative officer not a criminal fine as referred to in Article 10 of the Criminal Code which is decided by a criminal justice judge. ${ }^{25}$

The immigration polisional law enforcement function is subject to the provisions of the State administration. This can be seen from the opening of the opportunity for those subject to law enforcement actions to object. The objections to immigration polisional actions are regulated according to the principles and legal rules of the State administration and administrative justice. Therefore, the lawsuit against the decision of the administrative immigration sanction action is the domain of the State Administrative Court (Pengadilan Tata Usaha Negara, hereinafter as PTUN). If the objection is rejected with the issuance of the decision to reject the objection, then the rejected party can file a lawsuit with the PTUN (second level examination). The decision to reject the submission of an objection is considered as a firstlevel examination. ${ }^{26}$ The Table 1 below explains the legal basis for foreigners subject to Immigration Administration sanctions and their legal remedies:

Table 1. Administrative Santion in Immigration Crimes

\begin{tabular}{|c|c|c|}
\hline NO & ARTICLE & $\begin{array}{l}\text { TYPE OF ACTIONS } \\
\end{array}$ \\
\hline 1 & Article 75 & $\begin{array}{l}\text { (1) The Immigration Official has the authority to carry out } \\
\text { Administrative Immigration Acts against Foreigners who are in } \\
\text { the Territory of Indonesia who carry out dangerous activities and } \\
\text { should be suspected to endanger public security and order or do } \\
\text { not respect or disobey laws or regulations. }\end{array}$ \\
\hline
\end{tabular}

23 Barda Nawawi Arief, Kapita Selekta Hukum Pidana, Bandung, Citra Aditya Bhakti, 2003, pp. 13-14.

24 Imam Santoso, Op.Cit., p. 51

25 Ibid, p. 54.

26 Ibid 


\begin{tabular}{|c|c|c|c|}
\hline & & (3) & $\begin{array}{l}\text { Acts of Immigration Administrative sanctions as referred to in } \\
\text { paragraph (1) may be in the form of: } \\
\text { a. Inclusion in the list of Prevention or Deterrence } \\
\text { b. Restrictions, changes, or cancellations of Stay Permit } \\
\text { c. Prohibition to be in one or several specific places in the } \\
\text { Territory of Indonesia } \\
\text { d. The requirement to reside in a certain place in the Territory } \\
\text { of Indonesia } \\
\text { e. Charging fees; and / or } \\
\text { f. Deportation from Indonesian Territory. } \\
\text { Immigration Administration Act in the form of Deportation } \\
\text { can also be carried out against foreigners who are in the } \\
\text { Territory of Indonesia for trying to avoid the threat and } \\
\text { execution of punishment in their home country. }\end{array}$ \\
\hline 2 & Article 76 & & $\begin{array}{l}\text { Decisions regarding Immigration Administration Measures } \\
\text { as referred to in Article } 75 \text { paragraph (1) and paragraph (3) } \\
\text { are made in writing and must be accompanied by reasons. }\end{array}$ \\
\hline 3 & Article 77 & (2) & $\begin{array}{l}\text { Foreigners subject to Immigration Administration Act may } \\
\text { submit objections to the Minister. } \\
\text { The Minister may grant or reject the objection filed by a } \\
\text { Foreigner as referred to in paragraph (1) by Ministerial } \\
\text { Decree. } \\
\text { The Ministerial Decree as referred to in paragraph (2) is } \\
\text { final. } \\
\text { Filing an objection raised by a Foreigner does not delay the } \\
\text { implementation of the Immigration Administrative } \\
\text { Measures against the person concerned. }\end{array}$ \\
\hline 4 & Article 78 & $\begin{array}{l}\text { (2) } \\
\text { (3) }\end{array}$ & $\begin{array}{l}\text { Foreign Permit holders who have ended their validity period } \\
\text { and are still in the Territory of Indonesia less than } 60 \text { (sixty) } \\
\text { days from the deadline of the Stay Permit are subject to an } \\
\text { expense in accordance with statutory provisions. } \\
\text { Foreigners who do not pay the fees referred to in paragraph } \\
\text { (1) are subject to Immigration Administration Measures } \\
\text { Foreign Permit holders who have ended their validity and } \\
\text { are still in Indonesian Territory more than } 60 \text { (sixty) days } \\
\text { from the time limit of the Stay Permit are subjected to } \\
\text { Immigration Administrative Measures in the form of } \\
\text { Deportation and Determination. }\end{array}$ \\
\hline 5 & Article 79 & & $\begin{array}{l}\text { The person in charge of transportation equipment that does } \\
\text { not fulfill the obligations referred to in Article } 18 \text { paragraph } \\
\text { (1) is subject to an expense. }\end{array}$ \\
\hline 6 & Article 80 & & $\begin{array}{l}\text { Charges as referred to in Article } 19 \text { paragraph (4) and Article } \\
79 \text { constitute one of the Non-Tax State Revenues in the } \\
\text { Immigration field. }\end{array}$ \\
\hline
\end{tabular}

On the other hands, there is an immigration law enforcement function with criminal sanctions which is one of a series in the criminal justice process, therefore it is subject to criminal procedural law. Objections to an investigation may file a pretrial. Law Number 6 of 2011 concerning Immigration is an administrative law supplemented with criminal sanctions. Immigration crimes regulated in the criminal provisions chapter of Law Number 6 of 2011 concerning Immigration is part of administrative criminal law, namely criminal law in the field of administrative violations classified as 
administrative crime. ${ }^{27}$ The use of criminal sanctions in administrative law is essentially part of criminal law policy (penal policy). ${ }^{28}$ The following Table 2 explains the forms of criminal acts regulated in Law Number 6 of 2011 concerning Immigration.

\section{Table 2 Articles Containing the Formulation of Immigration Crimes in Law Number 6 of 2011 concerning Immigration}

\begin{tabular}{|c|c|c|c|}
\hline ARTICLE & SUBJECT & TYPE OF ACTIONS & PUNISHMENT \\
\hline $\begin{array}{l}\text { Article } \\
113\end{array}$ & Each person & $\begin{array}{l}\text { Deliberately entering or leaving } \\
\text { the Territory of Indonesia that } \\
\text { is not through the inspection of } \\
\text { Immigration Officials at the } \\
\text { Immigration Check Point. }\end{array}$ & $\begin{array}{l}\text { A maximum of } 1 \text { year in } \\
\text { prison and / or a } \\
\text { maximum fine of Rp. } \\
100,000,000 \text { (one } \\
\text { hundred million } \\
\text { rupiah). }\end{array}$ \\
\hline \multirow[t]{2}{*}{$\begin{array}{l}\text { Article } \\
114\end{array}$} & $\begin{array}{l}\text { Corporation, } \\
\text { Captain }\end{array}$ & $\begin{array}{l}\text { (1) Conveyance that enters or } \\
\text { exits the Territory of } \\
\text { Indonesia with its } \\
\text { conveyance which is not } \\
\text { through the Immigration } \\
\text { Check Point. }\end{array}$ & $\begin{array}{l}\text { A maximum of } 1 \\
\text { year in prison and / } \\
\text { or a maximum fine } \\
\text { of Rp. 100,000.00.00 } \\
\text { (one hundred } \\
\text { million rupiah). }\end{array}$ \\
\hline & & $\begin{array}{l}\text { (2) A conveyance that } \\
\text { intentionally unlocks or } \\
\text { raises passengers who do not } \\
\text { go through an Immigration } \\
\text { Official's inspection or } \\
\text { landing inspection officer at } \\
\text { the Immigration Check } \\
\text { Point }\end{array}$ & $\begin{array}{l}\text { A maximum of } 2 \\
\text { (two) years } \\
\text { imprisonment and / } \\
\text { or a maximum fine } \\
\text { of Rp. } \\
200,000,000.00 \text { (two } \\
\text { hundred million } \\
\text { rupiah). }\end{array}$ \\
\hline $\begin{array}{l}\text { Article } \\
115\end{array}$ & $\begin{array}{l}\text { Corporation } \\
\text { Captain }\end{array}$ & $\begin{array}{l}\text { Transportation that does not } \\
\text { pay the burden of the costs as } \\
\text { in Article } 19 \text { paragraph (4) and } \\
\text { Article } 79 .\end{array}$ & $\begin{array}{l}\text { A maximum of } 1 \text { (one) } \\
\text { year imprisonment and } \\
\text { / or a maximum fine of } \\
\text { Rp. } 100,000,000.00 \text { (one } \\
\text { hundred million } \\
\text { rupiah). }\end{array}$ \\
\hline $\begin{array}{l}\text { Article } \\
116\end{array}$ & Foreigners & $\begin{array}{l}\text { Not performing their } \\
\text { obligations as referred to in } \\
\text { Article } 71 .\end{array}$ & $\begin{array}{l}\text { Imprisonment for a } \\
\text { maximum of } 3 \text { months } \\
\text { or a maximum fine of } \\
\text { Rp. } 25,000,000.00 \\
\text { (twenty-five million } \\
\text { rupiah). }\end{array}$ \\
\hline $\begin{array}{l}\text { Article } \\
117\end{array}$ & $\begin{array}{l}\text { Owner, } \\
\text { Caretaker of } \\
\text { the Place } \\
\text { Lodging }\end{array}$ & $\begin{array}{l}\text { Does not provide information or } \\
\text { do not provide data on } \\
\text { Foreigners who stay at their } \\
\text { homes or accommodation after } \\
\text { being requested by the } \\
\text { Immigration Officer in charge }\end{array}$ & $\begin{array}{l}\text { Imprisonment for a } \\
\text { maximum of } 3 \text { months } \\
\text { or a maximum fine of } \\
\text { Rp. } 25,000,000.00 \\
\text { (twenty-five million } \\
\text { rupiah). }\end{array}$ \\
\hline
\end{tabular}

27 Barda Nawawi Arief, Op.Cit., p. 14.

28 Ibid, p. 15. 


\begin{tabular}{|c|c|c|c|c|}
\hline $\begin{array}{l}\text { Article } \\
118\end{array}$ & $\begin{array}{l}\text { Every } \\
\text { guarantor }\end{array}$ & $\begin{array}{l}\mathrm{D} \\
\text { th } \\
\mathrm{m} \\
\mathrm{re} \\
\mathrm{pe} \\
(3\end{array}$ & $\begin{array}{l}\text { liberately giving evidence } \\
\text { at is incorrect or does not } \\
\text { eet the guarantees given as } \\
\text { ferred to in Article } 63 \\
\text { ragraph (2) and paragraph } \\
\end{array}$ & $\begin{array}{l}\text { The maximum } \\
\text { imprisonment of } 5 \text { years } \\
\text { and a maximum fine of } \\
\text { Rp. } 500,000,000.00 \text { (five } \\
\text { hundred million } \\
\text { rupiah). }\end{array}$ \\
\hline $\begin{array}{l}\text { Article } \\
119\end{array}$ & Foreigners & (1) & $\begin{array}{l}\text { Deliberately using Travel } \\
\text { Documents, but it is known } \\
\text { or reasonably suspected that } \\
\text { the Travel Documents are } \\
\text { fake or falsified }\end{array}$ & 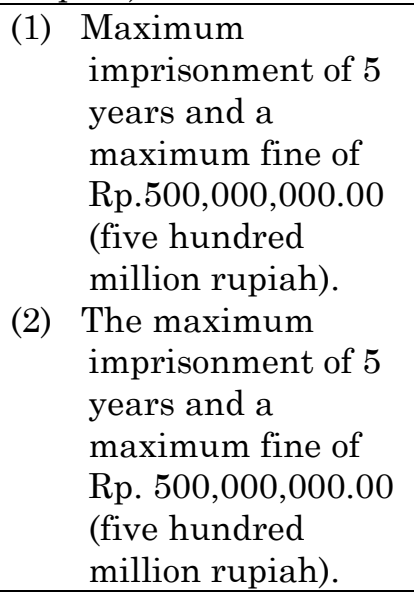 \\
\hline $\begin{array}{l}\text { Article } \\
120\end{array}$ & Each person & (2) & $\begin{array}{l}\text { Perform actions intended to } \\
\text { seek benefits, either directly } \\
\text { or indirectly, for oneself or } \\
\text { others by bringing someone } \\
\text { or groups of people, both } \\
\text { organized and disorganized, } \\
\text { or ordering others to bring } \\
\text { someone or groups of people } \\
\text { who do not have the right to } \\
\text { enter Indonesian territory } \\
\text { legally, whether using legal } \\
\text { or fake documents, or } \\
\text { without using travel } \\
\text { documents, whether through } \\
\text { immigration checks or not. } \\
\text { Attempts to Smuggle } \\
\text { Humans as verse } 1 .\end{array}$ & $\begin{array}{l}\text { (1) Criminal for human } \\
\text { smuggling with a } \\
\text { prison term of at } \\
\text { least } 5 \text { (five) years } \\
\text { and a maximum of } \\
15 \text { years and a } \\
\text { criminal fine of at } \\
\text { least Rp. } \\
500,000,000.00 \text { (five } \\
\text { hundred million } \\
\text { rupiah) and a } \\
\text { maximum of } \\
\text { Rp.1,500,000,000.00 } \\
\text { (one billion five } \\
\text { hundred million } \\
\text { rupiah). } \\
\text { Punished with } \\
\text { paragraph (1) }\end{array}$ \\
\hline $\begin{array}{l}\text { Article } \\
121\end{array}$ & $\begin{array}{l}\text { Every } \\
\text { Person }\end{array}$ & (b) & $\begin{array}{l}\text { Deliberately fake or falsify a } \\
\text { Visa or Entry or Residence } \\
\text { Permit with the intention to } \\
\text { use it for themselves or } \\
\text { others to enter or exit } \\
\text { Indonesian territory. } \\
\text { Deliberately using a fake or } \\
\text { falsified Visa or Entry } \\
\text { Permit or Residence Permit } \\
\text { to enter or exit or be in the } \\
\text { Territory of Indonesia. }\end{array}$ & $\begin{array}{l}\text { The maximum } \\
\text { imprisonment of } 5 \text { years } \\
\text { and a maximum fine of } \\
\text { Rp. } 500,000,000.00 \text { (five } \\
\text { hundred million } \\
\text { rupiah). }\end{array}$ \\
\hline $\begin{array}{l}\text { Article } \\
122\end{array}$ & $\begin{array}{l}\text { Ever } \\
\text { Person, } \\
\text { Foreigners }\end{array}$ & (a) & $\begin{array}{l}\text { Deliberately misusing or } \\
\text { carrying out activities that } \\
\text { are not in accordance with } \\
\text { the intent and purpose of }\end{array}$ & $\begin{array}{l}\text { Imprisonment for a } \\
\text { maximum of } 5 \text { years } \\
\text { and a maximum fine of } \\
\text { Rp.500,000,000.00 (five }\end{array}$ \\
\hline
\end{tabular}




\begin{tabular}{|c|c|c|c|c|}
\hline & & (b) & $\begin{array}{l}\text { granting a Stay Permit } \\
\text { granted to him. } \\
\text { Telling or giving } \\
\text { opportunities to Foreigners } \\
\text { to abuse or carry out } \\
\text { activities that are not in } \\
\text { accordance with the purpose } \\
\text { or purpose of granting a } \\
\text { Stay Permit granted to him. }\end{array}$ & $\begin{array}{l}\text { hundred million } \\
\text { rupiah). }\end{array}$ \\
\hline $\begin{array}{l}\text { Article } \\
123\end{array}$ & $\begin{array}{l}\text { Each } \\
\text { person, } \\
\text { Foreigners }\end{array}$ & $\begin{array}{l}\text { (a) } \\
\text { (b) }\end{array}$ & $\begin{array}{l}\text { Deliberately providing false } \\
\text { or falsified letters or data or } \\
\text { incorrect information with a } \\
\text { view to obtaining a Visa or } \\
\text { Stay Permit for himself or } \\
\text { others. } \\
\text { Deliberately use a Visa or } \\
\text { Stay Permit as referred to in } \\
\text { letter a to enter and / or exit } \\
\text { and / or be in the Territory } \\
\text { of Indonesia. }\end{array}$ & $\begin{array}{l}\text { Imprisonment for a } \\
\text { maximum of } 5 \text { years } \\
\text { and a maximum fine of } \\
\text { Rp.500,000,000.00 (five } \\
\text { hundred million } \\
\text { rupiah). }\end{array}$ \\
\hline $\begin{array}{l}\text { Article } \\
124\end{array}$ & Each person & 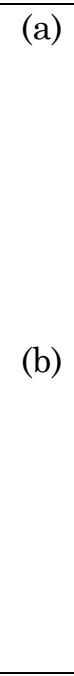 & $\begin{array}{l}\text { Deliberately hiding or } \\
\text { protecting or providing } \\
\text { accommodation or providing } \\
\text { livelihood or providing work } \\
\text { to foreigners who are known } \\
\text { or reasonably suspected of } \\
\text { being in Indonesian } \\
\text { territory illegally } \\
\text { His residence permit has } \\
\quad \text { expired }\end{array}$ & $\begin{array}{l}\text { (a) } \begin{array}{l}\text { A maximum of } 2 \\
\text { years imprisonment } \\
\text { and / or a maximum } \\
\text { fine of } \\
\text { Rp.200,000,000.00 } \\
\text { (two hundred } \\
\text { million rupiah). } \\
\text { (b) A maximum } \\
\text { sentence of } 3 \\
\text { months } \\
\text { imprisonment or a } \\
\text { maximum fine of } \\
\text { Rp. } 25,000,000.00 \\
\text { (twenty-five million } \\
\text { rupiah) }\end{array} \\
\end{array}$ \\
\hline $\begin{array}{l}\text { Article } \\
125\end{array}$ & Foreigners & \multicolumn{2}{|r|}{$\begin{array}{l}\text { Without permission it is located } \\
\text { in certain areas that have been } \\
\text { declared prohibited by } \\
\text { foreigners as referred to in } \\
\text { Article } 48 \text { paragraph (4). }\end{array}$} & $\begin{array}{l}\text { The maximum } \\
\text { imprisonment is } 3 \text { years } \\
\text { and / or a criminal fine } \\
\text { of } R p .300,000,000.00 \\
\text { (three hundred million } \\
\text { rupiah). }\end{array}$ \\
\hline $\begin{array}{l}\text { Article } \\
126\end{array}$ & Each person & . & $\begin{array}{l}\text { Use Indonesian Travel } \\
\text { Documents to enter or exit } \\
\text { Indonesian Territory, but it } \\
\text { is known or reasonably } \\
\text { suspected that Indonesian } \\
\text { Travel Documents are fake } \\
\text { or falsified. } \\
\text { Use the Indonesian Travel } \\
\text { Document of another person } \\
\text { or that has been revoked or } \\
\text { declared canceled to enter or } \\
\text { exit the Territory of } \\
\text { Indonesia or submit to }\end{array}$ & 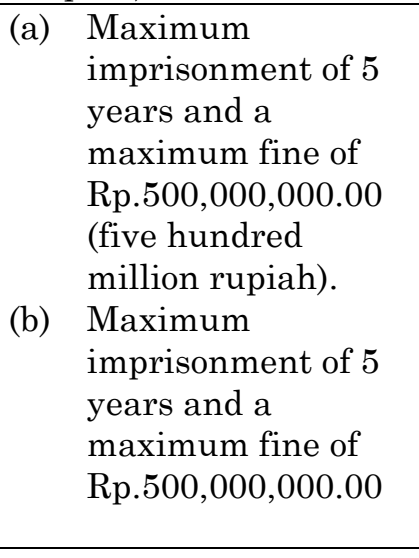 \\
\hline
\end{tabular}




\begin{tabular}{|c|c|c|c|c|}
\hline & & $\begin{array}{l}\text { another person the } \\
\text { Indonesian Travel } \\
\text { Document given to him or } \\
\text { owned by someone else for } \\
\text { the purpose of being used } \\
\text { without rights. } \\
\text { (c) Providing invalid data or } \\
\text { incorrect information to } \\
\text { obtain Indonesian Travel } \\
\text { Document for himself or } \\
\text { others. } \\
\text { (d) Possessing or using } \\
\text { unlawfully } 2 \text { or more similar } \\
\text { Indonesian Travel } \\
\text { Documents and all of them } \\
\text { are still valid } \\
\text { (e) Faking Indonesian Travel } \\
\text { Documents or making fake } \\
\text { Indonesian Travel } \\
\text { Documents with the intent } \\
\text { to be used for himself or } \\
\text { others. }\end{array}$ & (d) & $\begin{array}{l}\text { Maximum } \\
\text { imprisonment of } 5 \\
\text { years and a } \\
\text { maximum fine of } \\
\text { Rp.500,000,000.00 } \\
\text { (five hundred } \\
\text { million rupiah). } \\
\text { A maximum of } 5 \\
\text { years imprisonment } \\
\text { and a maximum fine } \\
\text { of } \\
\text { Rp.500,000,000.00 } \\
\text { (five hundred } \\
\text { million rupiah). } \\
\text { The maximum } \\
\text { imprisonment of } 5 \\
\text { years and a } \\
\text { maximum fine of } \\
\text { Rp. 500,000,000.00 } \\
\text { (five hundred } \\
\text { million rupiah). }\end{array}$ \\
\hline $\begin{array}{l}\text { Article } \\
127\end{array}$ & Each person & $\begin{array}{l}\text { Deliberately and illegally } \\
\text { storing fake or falsified } \\
\text { Indonesian Travel Documents } \\
\text { with a view to use for himself or } \\
\text { others }\end{array}$ & & $\begin{array}{l}\text { aximum } \\
\text { iprisonment of } 5 \text { years } \\
\text { d a maximum fine of } \\
0.500,000,000.00 \text { (five } \\
\text { andred million } \\
\text { piah). }\end{array}$ \\
\hline $\begin{array}{l}\text { Article } \\
128\end{array}$ & Each person & $\begin{array}{l}\text { (a) Deliberately and unlawfully } \\
\text { printing, possessing, storing, } \\
\text { or trading blank Indonesian } \\
\text { Travel Documents or other } \\
\text { Immigration Documents } \\
\text { blanks. } \\
\text { (b) Deliberately and unlawfully } \\
\text { creating, possessing, storing, } \\
\text { or trading stamp or other } \\
\text { tools used to certify } \\
\text { Indonesian Travel } \\
\text { Documents or other } \\
\text { Immigration Documents. }\end{array}$ & & $\begin{array}{l}\text { e maximum } \\
\text { prisonment of } 5 \text { years } \\
\text { d a maximum fine of } \\
\text { andred million } 500,000,000.00 \text { (five } \\
\text { piah). }\end{array}$ \\
\hline $\begin{array}{l}\text { Article } \\
129\end{array}$ & Each person & $\begin{array}{l}\text { Deliberately and unlawfully for } \\
\text { the benefit of oneself or others } \\
\text { damaging, changing, adding to, } \\
\text { reducing, or eliminating, in part } \\
\text { or in whole, the information or } \\
\text { stamp contained in the } \\
\text { Indonesian Travel Document or } \\
\text { other Immigration Document. }\end{array}$ & & $\begin{array}{l}\text { aximum } \\
\text { prisonment of } 5 \text { years } \\
\text { d a maximum fine of } \\
.500,000,000.00 \text { (five } \\
\text { andred million } \\
\text { piah). }\end{array}$ \\
\hline
\end{tabular}




\begin{tabular}{|c|c|c|c|}
\hline $\begin{array}{l}\text { Article } \\
130\end{array}$ & Each person & $\begin{array}{l}\text { Deliberately and unlawfully } \\
\text { possessing another person's } \\
\text { Travel Document or } \\
\text { Immigration Document. }\end{array}$ & $\begin{array}{l}\text { A maximum of } 2 \text { years } \\
\text { imprisonment and / or a } \\
\text { maximum fine of } \\
\text { Rp.200,000,000.00 (two } \\
\text { hundred million } \\
\text { rupiah). }\end{array}$ \\
\hline $\begin{array}{l}\text { Article } \\
131\end{array}$ & Each person & $\begin{array}{l}\text { Intentionally without rights } \\
\text { and against the law owning, } \\
\text { storing, destroying, eliminating, } \\
\text { modifying, duplicating, using } \\
\text { and or accessing immigration } \\
\text { data, either manually or } \\
\text { electronically, for the benefit of } \\
\text { oneself or others. }\end{array}$ & $\begin{array}{l}\text { Maximum } \\
\text { imprisonment of } 5 \text { years } \\
\text { and a maximum fine of } \\
\text { Rp. 500,000,000.00 (five } \\
\text { hundred million } \\
\text { rupiah). }\end{array}$ \\
\hline $\begin{array}{l}\text { Article } \\
132\end{array}$ & $\begin{array}{l}\text { Immigration } \\
\text { Officer }\end{array}$ & $\begin{array}{l}\text { Intentionally and against the } \\
\text { law giving Indonesian Travel } \\
\text { Documents and / or giving or } \\
\text { extending Immigration } \\
\text { Documents to someone who } \\
\text { they know is not entitled. }\end{array}$ & $\begin{array}{l}\text { The maximum prison } \\
\text { term is } 7 \text { years. }\end{array}$ \\
\hline $\begin{array}{l}\text { Article } \\
133\end{array}$ & $\begin{array}{l}\text { Immigration } \\
\text { Office, } \\
\text { Other } \\
\text { Offices }\end{array}$ & $\begin{array}{l}\text { (a) Allowing someone to } \\
\text { commit immigration } \\
\text { crimes in Article 118, } \\
\text { Article 119, Article 120, } \\
\text { Article 121, Article 122, } \\
\text { Article 123, Article 126, } \\
\text { Article 127, Article 128, } \\
\text { Article 129, Article 131, } \\
\text { Article 132, Article 133 } \\
\text { letter b, Article } 134 \\
\text { letter b and Article } 135 \\
\text { which should be known } \\
\text { by him. } \\
\text { (b) Deliberately leaking } \\
\text { confidential } \\
\text { Immigration data to } \\
\text { unauthorized parties as } \\
\text { in Article } 67 \text { paragraph } \\
\text { (2) and Article } 68 \\
\text { paragraph (2). } \\
\text { (c) Intentionally failing to } \\
\text { carry out standard } \\
\text { operating procedures } \\
\text { that apply in the } \\
\text { inspection process of } \\
\text { departure or arrival at } \\
\text { the Immigration } \\
\text { Checkpoint which } \\
\text { results in the entry of } \\
\text { foreigners into the } \\
\text { Indonesian Territory as } \\
\text { in Article 13 paragraph } \\
\text { (1) or the departure of } \\
\text { people from the } \\
\text { Indonesian Territory as }\end{array}$ & $\begin{array}{l}\text { (c) The maximum } \\
\text { imprisonment is } 2 \\
\text { years. }\end{array}$ \\
\hline
\end{tabular}




\begin{tabular}{|c|c|c|c|c|}
\hline & & $\begin{array}{l}\text { (d) } \\
\text { (e) }\end{array}$ & $\begin{array}{l}\text { referred to in Article } 16 \\
\text { paragraph (1). ). } \\
\text { Intentionally and } \\
\text { against the law not } \\
\text { carrying out standard } \\
\text { operating procedures for } \\
\text { detention of Detainees } \\
\text { at the Immigration } \\
\text { Detention Center or } \\
\text { Immigration Detention } \\
\text { Room which resulted in } \\
\text { Detainees running } \\
\text { away. } \\
\text { Intentionally and } \\
\text { against the law do not } \\
\text { enter data into the } \\
\text { Immigration } \\
\text { Management } \\
\text { Information System as } \\
\text { referred to in Article } 70 .\end{array}$ & $\begin{array}{l}\text { (e) The maximum } \\
\text { imprisonment is } 6 \\
\text { months. }\end{array}$ \\
\hline $\begin{array}{l}\text { Article } \\
134\end{array}$ & $\begin{array}{l}\text { Every } \\
\text { detainee }\end{array}$ & $\begin{array}{l}\text { (a) } \\
\text { (b) }\end{array}$ & $\begin{array}{l}\text { Knowingly } \\
\text { manufacture, possess, } \\
\text { use, and / or distribute } \\
\text { weapons. } \\
\text { Deliberately running } \\
\text { away from the } \\
\text { Immigration Detention } \\
\text { Center or Immigration } \\
\text { Detention Room. }\end{array}$ & $\begin{array}{l}\text { (a) The maximum } \\
\text { imprisonment is } \\
3 \text { years. } \\
\text { (b) } 5 \text { years } \\
\text { imprisonment. }\end{array}$ \\
\hline $\begin{array}{l}\text { Article } \\
135\end{array}$ & Each person & \multicolumn{2}{|c|}{$\begin{array}{l}\text { Conducting a pseudo marriage } \\
\text { with the aim of obtaining } \\
\text { immigration documents and / or } \\
\text { to obtain Indonesian citizenship } \\
\text { status }\end{array}$} & $\begin{array}{l}\text { The maximum } \\
\text { imprisonment is } 5 \text { years } \\
\text { and a maximum fine of } \\
\text { Rp. } 500,000,000.00 \text { (five } \\
\text { hundred million } \\
\text { rupiah). }\end{array}$ \\
\hline $\begin{array}{l}\text { Article } \\
136\end{array}$ & Corporation & (1) & $\begin{array}{l}\text { In the event that the } \\
\text { criminal acts as meant } \\
\text { in Article } 114 \text {, Article } \\
116 \text {, Article } 117 \text {, Article } \\
118 \text {, Article } 120 \text {, Article } \\
124 \text {, Article } 128 \text { and } \\
\text { Article } 129 \text { are } \\
\text { committed by the } \\
\text { corporation. }\end{array}$ & $\begin{array}{l}\text { (1) Criminal is imposed } \\
\text { on the management } \\
\text { and the corporation. } \\
\text { (2) Imposition of } \\
\text { punishment against } \\
\text { a corporation is only } \\
\text { a fine with a } \\
\text { provision of } 3 \text { times } \\
\text { the amount of the } \\
\text { fine in paragraph } \\
\text { (1). } \\
\text { (3) The criminal } \\
\text { provisions as } \\
\text { referred to in } \\
\text { Article } 113 \text {, Article } \\
119, \text { Article } 121 \\
\text { letter b, Article } 123 \\
\text { letter b, and Article } \\
126 \text { letter a and } \\
\text { letter b shall not be }\end{array}$ \\
\hline
\end{tabular}


applied to victims of

trafficking and

human smuggling.

Above already described the administrative sanctions and criminal sanctions in Law Number 6 Year 2011 concerning Immigration, for the sake of realizing justice in the enforcement of the Immigration law, it must be based on national standards recognized by the nations with respect. In addition to welfare and social considerations, the upcoming reform of the National Legal System and the National Criminal Law System will restore the criminal function as an ultimum remedium with the awareness that the prevailing criminal law system is a legacy of the classical tradition that views criminal sanctions as retaliation. for the actions of someone who violates the norms of criminal law.

The reform of the National Legal System and the National Criminal Law System that will be formed will develop a new paradigm colored by modern trends that view criminal sanctions as the last means. If the aspects of justice and benefit take precedence over legal certainty, it means that the nation consciously uses social welfare as the goal of punishment.

In line with this view, Muladi firmly states that the Criminal Justice System in the short term aims at resocializing the perpetrators of criminal acts, the medium term in the form of crime control and the long term in the form of social welfare.

Associated with the doctrine of legal science, that efforts to form legal politics in tackling crime can take various forms. The first form is repressive using penal means, including in this case the criminalization process. Development of criminal law policies in the field of immigration using a double track system formula (formulation of criminal acts and sanctions).

According to Wirjono Prodjodikoro, stated that prevention efforts without punishment (without using penal means) should always take precedence. It is better for people who commit criminal acts to be punished with administrative sanctions in order to achieve the goal of straightening the social balance, punishment can be applied as an ultimum remedium or the last means of punishing people. The question arises when there should be criminal sanctions and administrative sanctions.

Noot is met nauwkeurigheid aan te geven, waar de grens ligt tussen strafrecht en civiel recht, tussen strafrecht en tuchtrecht, tussen strafrecht en administratief recht. ${ }^{29}$

29 Ibid 
It can never be said precisely where the boundary lies between criminal law and administrative law.

Romli Atmasasmita gave the view that the classic criminal principle in the form of expulsion in practice cannot create a comfortable, just and beneficial climate of community life for both the community and the suspect, defendant or convict. On the other hand, there has been a density of prisoners who have exceeded the capacity limit and have resulted in sexual, social and security demoralization in prisons, and there has even been an increase in the quality of criminal acts so that they are often called "crime high school prisons". ${ }^{30}$ The detterence effect that is expected does not happen, even the recidivist is increasing, the significant impact and not previously predicted by adherents of retribution is a waste of state costs for law enforcement, both in the institutional aspect and in the aspect of financing criminal cases, the advantages and disadvantages in the application of criminal sanctions must be considered in imposing criminal sanctions. ${ }^{31}$

Based on this background, in this paper the authors propose several problems, namely how to apply the principle of ultimum remedium in Law Number 6 of 2011 concerning Immigration which contains a double track system between administrative sanctions and criminal sanctions, to get a better understanding as well. presented a comparison of immigration law enforcement in Indonesia with Japan, Malaysia, and Singapore. To see the holistic law enforcement process, in immigration law enforcement it can be seen the process of one example of a concrete case in Decision Number 01/PID.SUS/2018/PN.TNG, Decision Number 02/PID.SUS/2018/PN.TNG with the accused Besmillah Qasemi and Shaqera Qasemi are both charged guilty of violating Article 116 Jo Article 71 letter b of Law Number 6 of 2011 concerning Immigration, it is interesting to discuss because there is a Member Judge who is Dissenting Opinion on the basis that foreigners who claim to be asylum seekers should not be able to was convicted before an official letter from The United Nations High Commissioner For Refugees (UNHCR) stated that the foreigner was not an asylum seeker. ${ }^{32}$

30 Romli Atmasasmita, Rekonstruksi Asas Tiada Pidana Tanpa Kesalahan Geen Straf Zonder Schuld, Jakarta, PT Gramedia Pustaka Utama, 2017, pp. 16-18.

31 Ibid

32 It is stated that: "Every foreigner who is in the territory of Indonesia is obliged to show and submit travel documents or residence permits in his possession if requested by an immigration official who is in charge of immigration control, shall be punished with imprisonment of 3 (three) months or a maximum fine of at most. a lot of Rp. 25,000,000.00 (twentyfive million rupiah)." (see Indonesia Law Number 6 of 2011 concerning Immigration, State Gazette of the Republic of Indonesia of 2011 Number 5216). 
In this case the defendant entered Indonesia without legal documents, the PPNS investigator argued that this foreigner entered Indonesia deliberately to throw away his legal documents, due to his mistake the defendant was placed in the Immigration Detention Center for 4 months, the Public Prosecutor charged the defendant with a criminal offense. confinement for 2 months. The Panel of Judges gave a verdict of 1 month in prison against the defendant, the defendant then served a sentence of 1 month in prison in Tangerang. The problem again arose when the defendant applied for asylum seeker status, after completing his one month imprisonment, the defendant was sent to the Immigration Detention Center in Tanjung Pinang, of course the immigration authorities could not make deportation efforts before waiting for the legal status issued by The United Nations High Commissioner For Refugees (UNHCR). This results in unclear enforcement of Immigration law in Indonesia which can cause losses to violators of the Immigration Law, Society, and the State of Indonesia.

The author also analyzed the Denpasar District Court Preliminary Decision Number 3 / Pid.Pra / 2019 / PN Dps, the judge rejected the pretrial petition. ${ }^{33}$ Rabie Abderahmad Ayad, a Lebanese national who has been arrested and later detained by the Bali Regional Police based on the Red Notice issued by the United States Government in the context of the prosecution process in the United States, Rabie Abderahmad Ayad has served 342 (three hundred and forty two) days of detention, due to a request for extradition from the United States government. ${ }^{34}$

With the authority possessed by Immigration officials to determine whether to impose administrative or criminal sanctions, it is better to solve them like tax cases where the settlement is mostly done administratively in their respective regions. This can be done also in cases of immigration.

The subject matter in the pretrial filing is related to the detention carried out by the respondent (Bali Regional Police) on April 19, 2018, violating the period of detention stipulated in Law Number 1 of 1979 concerning Extradition so that it does not provide legal certainty for foreigners and prolonged detention is form of torture or torture. These cases can be resolved quickly, simply and at low cost as well as a clear legal basis if resolved with immigration administrative sanctions in the form of deportation and deterrence so as to realize the application of the principle of ultimum remedium in Law Number 6 of 2011 concerning Immigration.

This paper analyses the application of the ultimum remedium principle in immigration crime. Immigration law enforcement requires immigration

33 Denpasar District Court Decision Number 03/Pid.Pra/2019/PN.Dps. 18 April 2019, p. 33

34 Ibid, p. 2 


\section{A. Bahari}

officials to strictly select the increasing entry and entry of foreigners in Indonesian territory and it is feared that it could disturb the stability of the security of the Indonesian State. Thus, immigration officers play an important role in implementing regulation of the traffic of people into and out of the territory of Indonesia. When foreigners commit violations and legal crimes in Law Number 6 of 2011 concerning Immigration, immigration officials will impose sanctions either in the form of administrative sanctions or criminal sanctions. In imposing punishment, Immigration Officers must consider the principle of ultimum remedium which implies that criminal sanctions are used as a last resort, meaning that in violations of law that occur in Law Number 6 of 2011 concerning Immigration, they must prioritize administrative sanctions. How the benchmarks to measure the application of the ultimum remedium principle, will be answered by the extent to which the application of criminal sanctions and the administration of Immigration can provide benefits to both offenders, the community and for the welfare of the Indonesian people.

\section{B. Method}

In accordance with the problems raised in this study in order to be able to answer the research objectives, this research uses a research method with the following steps:

\section{Type of Research}

This type of research conducted in this research is normative research. Normative legal research or library research is legal research conducted by examining library materials or secondary data. Normative legal research includes research on legal principles, research on legal systems, research on the level of vertical and horizontal synchronization, legal comparisons and legal history. ${ }^{35}$ To see how the regulation, as well as the application of the Ultimum Remedium principle in the crime of immigration, by using the normative research method, the types of data that I will use are primary data and secondary data.

\section{Sources of Data}

The sources of data at this research divideds into 2 (two) types, as follows:

35 Soerjono Soekanto \& Sri Mamudji, Penelitian Hukum Normatif: Suatu Tinjauan Singkat, Jakarta, Rajawali Pres, 1999, p. 15. 
a. Primary Data, is data obtained directly by the author through interviews conducted with sources including:

1) Jaya Saputra, S.H, M.H., as Head of Sub-directorate of Immigration Detention and Deportation of the Directorate General of Immigration of the Republic of Indonesia on December 17, 2018.

2) Komang, S.H., M.H., as Head of Subdirectorate of Immigration Investigation on January 29, 2019.

3) Dilan, S.H., M.H., As Head of Subdirectorate of Immigration Enforcement on January 29, 2019.

4) Mitra Salima Suryono, as Associate External Relations / PI Officer of The United Nations High Commissioner for Refugees (UNHCR) on 20 December 2018.

5) Paulina, As Protection Associate of The United Nations High Commissioner for Refugees (UNHCR) on December 20, 2018.

6) Dr. Ahmad Sofian, S.H., M.A, as an academic from Bina Nusantara University on February 21, 2019.

7) Avyanthi Aziz, S. Sos., MS, as an academic from the University of Indonesia on August 20, 2018.

8) Ziko Nunius Fernando, S.H., M.H., CIL, as an Academician from the University of Palembang on 21 February 2019.

This interview was conducted to get an insight from the source regarding the application of the ultimum remedium principle in immigration crime, which is the problem in this thesis.

b. Secondary Data, is data that the authors obtain from literature studies. This secondary data consists of:

1) Primary Legal Materials

Legal material that is authoritative means that it has authority. ${ }^{36}$

Primary legal materials in the form of statutory regulations contain the rules needed to study immigration crime, including:

a) The 1945 Constitution.

b) Toelatingsbesluit (S. 1961 NO. 47).

c) Toelatingsbesluit (S. 1949 No. 331).

d) Law No. 42 Drt. 1950 concerning Immigration Fees.

e) Law No. 9 Drt. 1950 concerning Supervision of Foreigners.

f) Indonesian Criminal Code (KUHP)

g) Law Number 8 Year 1981 Concerning the Criminal Procedure Code.

36 Peter Mahmud Marzuki, Penelitian Hukum, Jakarta, Kencana Prenadamedia Group, 2014, p. 93. 
h) Law (DRT) Number 8 of 1955 concerning Immigration Crime.

i) Law Number 9 Year 1992 concerning Immigration.

j) Law Number 6 Year 2011 concerning Immigration.

k) Law Number 1 of 1979 concerning Extradition.

l) Law Number 1 Year 2006 concerning Reciprocal Assistance in Criminal Matters.

m) Presidential Regulation of the Republic of Indonesia Number 125 of 2016 concerning Handling of Refugees from Abroad.

n) Government Regulation Number 31 of 2011 concerning Implementing Regulations of Law Number 6 of 2011 concerning Immigration.

Apart from the law, other primary legal materials used were the decision of the Tangerang District Court Number 01 / Pid.Sus / 2018 / PN.Tng with the defendant Besmillah Qasemi and Decision Number 02 / Pid.Sus / 2018 / PN.Tng with the defendant Shaqera Qasemi and Denpasar District Court Preliminary Decision Number 3 / Pid.Pra / 2019 / PN Dps, This court decision will be used as a reference by the author to see how law enforcement against immigration crime in Indonesia.

2) Secondary Legal Materials

Represents all publications about the law that are not official documents. ${ }^{37}$ Legal materials used include textbooks, legal journals, papers of various scientific meetings, theses, theses, and other research results, as well as articles related to the application of the ultimum remedium principle in immigration crimes.

3) Tertiary Legal Materials

In the form of supporting materials that provide instructions and explanations for secondary materials, such as general dictionaries, law dictionaries, namely the Black's Law Dictionary.

\section{Data Collection Method}

The collected data will be analyzed using qualitative and descriptive methods, which are the implementation of in-depth, comprehensive and holistic data analysis to obtain conclusions on the problem under study. Analytical descriptive writing to provide a comprehensive picture of the facts and problems related to the object of research, then an analysis of these problems is carried out based on the prevailing legal norms and the theory used as analysis.

37 Ibid. 


\section{Result and Discussion}

\section{Immigration Crimes: History and Its Development}

Before formulating what is meant by the term immigration crime, below will briefly mention the use of the term criminal offense. The term "criminal offense" is a translation from the Dutch strafbaar feit or delic.38 Apart from the term criminal offense, the term strafbaar feit is also translated into various Indonesian languages, for example: (1) peristiwa pidana (criminal incident) ${ }^{39}$ (2) perbuatan yang boleh dihukum (an act than can be punished $)^{40}$ (3) pelanggaran pidana (criminal offense) ${ }^{41}$ (4) perbuatan pidana (criminal action). 42

Meanwhile, the definition of immigration is the matter of the traffic of people entering or leaving the Indonesian Territory and its supervision in the framework of maintaining the upholding of State sovereignty. ${ }^{43}$ Thus, the meaning of immigration crime is an act that is prohibited by immigration law, anyone who violates it is threatened with criminal sanctions as regulated in the Immigration Law.

The position of Immigration law as positive law is also included in public law, because violations of the Immigration Crime are in the framework of regulating public relations with their countries and their implementation is fully in the hands of the government and for the benefit of the people of the nation and the State. ${ }^{44}$

\section{a) History of Immigration Crime}

The 1924 International Conference on Emigration and Immigration in Rome, defines immigration as "human mobility to enter a country with its purpose to make a living or for residence." From this definition it is understood that immigration means the movement of people moving into a country with the intention of earning a living and settling there. ${ }^{45}$ The development of

38 H. Abdulla Sjahriful, Memperkenalkan Hukum Keimigrasian, Jakarta, Ghalia Indonesia, 1993, p. 108.

39 E. Utrecht, Hukum Pidana 1, Jakarta, Balai Buku Indonesia, 1958, p. 250.

40 Karni, Ringkasan Tentang Hukum Pidana, Jakarta, Balai Buku Indoenesia, 1950, p. 34; H. J. Van Schravendjik, Buku Pelajaran Tentang Hukum Pidana Indonesia, Jakarta, J. B. Wolters, 1956 , p. 87 .

41 M.H. Tirtaamidjaja, Pokok-Pokok Hukum Pidana, Jakarta, Fasco, 1955, p. 18.

42 Moeljatno, "Perbuatan Pidana dan Pertanggungan Jawab dalam Hukum Pidana", Speech on Anniversary Ceremony of Universitas Gajah Mada VI, Yogyakarta: Gajah Mada, 1955, pp. 8-9.

43 Article 1 (1) Immigration Law.

44 Sihar Sihombing, Hukum Imigrasi, Bandung, Nuansa Aulia, 2009, p. 78.

45 Imam Santoso, Op.Cit., p. 61. 


\section{A. Bahari}

immigration in Indonesia can be divided into two parts, namely before Indonesia became independent and after Indonesia became independent ${ }^{46}$ :

\section{1) Before the Colonialization}

Given Indonesia's strategic geographical location, where its position is on the equator which only recognizes two seasons, namely the rainy season and summer, it lies between the two continents of Asia and the continent of Australia and is located between the Indian Ocean and the Pacific Ocean, making Indonesia's homeland fertile. rich in natural products, forests, and sea. This situation makes foreigners want to come to Indonesia with various purposes and backgrounds. This can be seen from the records of foreign arrivals that are grouped according to nationality/nationality ${ }^{47}$ :

\begin{tabular}{cl}
\hline YEAR & NOTE \\
\hline $701-800$ & $\begin{array}{l}\text { First Immigration (Hindu) } \\
\text { Come to Indonesia to trade / trade and spread Hinduism and } \\
\text { culture. }\end{array}$ \\
\hline 1294 & $\begin{array}{l}\text { Second Immigration } \\
\text { The Chinese people / nation first came to Indonesia because of the } \\
\text { background of the civil war between the dynasties. In the second } \\
\text { stage, Chinese people came to Indonesia with an economic / } \\
\text { commercial nature. }\end{array}$ \\
\hline \multirow{2}{*}{1410} & $\begin{array}{l}\text { Third Immigration } \\
\text { Arabs came to Indonesia to spread religion. }\end{array}$ \\
\hline \multirow{2}{*}{1522} & $\begin{array}{l}\text { Fourth Immigration } \\
\text { The Portuguese came to Indonesia to trade, then colonized to } \\
\text { maintain their trade monopoly. }\end{array}$ \\
\hline Fifth Immigration \\
The Dutch first went to Indonesia to trade, then colonized to \\
secure and maintain their trade.
\end{tabular}

\section{2) In the Colonialization}

This colonial period can be broadly divided into two parts, namely the Dutch and Japanese colonial times ${ }^{48}$ :

\subsection{Dutch Colonial Period}

The wealth of natural resources, particularly as a producer of developmental commodities that are traded on the world market, has made Indonesia's territory, which is largely controlled by the Dutch East Indies, attracted various foreign countries to participate in developing the plantation commodity trading business. In order to regulate the flow of foreign arrivals to the Dutch East Indies, the colonial government in 1913

46 Sihar Sihombing, Op.Cit., p. 5.

47 Ibid.

48 Sihar Sihombing, Op.Cit., p. 6 
established the Office of the Secretary of the Immigration Commission and as its duties and functions continued to develop in 1921 the office of the Secretary of the Immigration Commission was changed to Immigratie (Immigration Service). ${ }^{49}$

The Immigration Service during the Dutch East Indies colonial rule was under Director Yustisi, whose organizational structure saw the formation of groups such as Visa afdeling. The ambtenaar immigratie corps is expanded. Experienced and highly educated personnel are employed at the center, not a few shipments from the Netherlands. All positions of the Immigration Service are in the hands of Dutch officials. ${ }^{50}$

The immigration policy established by the Dutch was open door politics (opendeur politiek), through this policy, the Dutch East Indies government opened as wide as possible for foreigners to enter, stay, and become citizens of the Dutch East Indies. The main purpose of implementing the "opendoor" immigration policy was to get allies of investors from various countries in order to develop the export of plantation commodities in the Balanda Indies region. In addition, the existence of foreigners can also be used to jointly exploit and suppress indigenous people. ${ }^{51}$ Although the addition of regional immigration offices continues to grow, the organizational structure is still relatively simple with three parts, namely: Entry permits, residence people, foreigner population, and citizenship. 52

The Immigration Policy of the Dutch East Indies Government was an opendoor politics (political opposition). The reasons the Dutch East Indies Government implemented opendoor politics were ${ }^{53}$ :

a) To attract foreign capital and foreign influence to Indonesia, so that it is difficult for Indonesia to move

b) In order for the Indonesian people to remain colonized

c) So that many defend Indonesia if there are foreign countries that attack and

d) To benefit foreign capital requires cheap labor.

49 Directorate of Immigration, Sejarah Direktorat Jenderal Imigrasi, http://www.imigrasi.go.id/index.php/profil/sejarah\#\%E2\%80\%A2-era-revolusikemerdekaan

50 Ibid.

51 Ibid.

52 Ibid.

53 Sihar Sihombing, Op.Cit., p. 7 


\section{A. Bahari}

Some regulations that can be noted at this time include:

a) Staatsblad 1913 Number 105 concerning Appointment of Secretary of the Immigration Commission in each government capital, namely: Batavia (Jakarta), Surabaya and Semarang.

b) Staatsblad 1916 Number 142 of 1916 was appointed a Secretary of the Immigration Commission in Pontianak and Pengankatan a Chinese interpreter for the purposes of the Immigration Service in Jakarta.

c) Staatsblad 1921 Number 33 dated January 13, it is explained that Immigration has stood alone under the name of the Immigration Service.

\subsection{Japanese Colonial Period}

Japanese entry into Indonesian territory in 1942. During the Japanese occupation there were almost no fundamental changes in immigration regulations. Dutch East Indies legal products are still used during this period. Things that can be noted during the Japanese era are as follows ${ }^{54}$ :

a) The registration of foreigners is introduced by means of a statement of foreign residence containing the identity of the foreigner. However, it is not clear whether it will replace immigration documents during the Dutch era or not.

b) There is proof of identity (idenditeits bewijs)

Furthermore, the existing immigration documents for Dutch products are still in use and in this case need to be modified according to needs only.

\section{3) After Indonesian Independence}

In this period, in general it can be further divided into two periods from 1945 to 1992 , there are several things that can be observed during this $\operatorname{period}^{55}$ :

\subsection{Year 11945-1949}

During the Dutch East Indies colonial period, the Immigration Service was under the Director Yustisi. Since 1945, in Aceh there has been its own Immigration Service under the Ministry of Justice. In 1946, the Ministry of Foreign Affairs issued a Certificate deemed as the (first) Passport which was issued to participate in the invitation to the Inter Asian Conference in New Delhi, led by H. Agus Salim in his position as the Deputy Minister of Information of the Republic of Indonesia.

54 Ibid.

55 Ibid. 
On January 3, 1946, Yogyakarta became the capital of the Republic of Indonesia, due to a break with the center, the Immigration Service was supervised by the Regional Head. Through the Instruction of the Head of Justice of Bukit Tinggi through his Instruction in 1947, the Immigration Service which was originally under the Ministry of Justice was changed to become under the Ministry of Foreign Affairs.

\subsection{Year 1949-1959}

This period was marked by the following:

a) October 5, 1949

With the issuance of the Decree of the State Secretary, the Head of the Yustisi Department of the Balanda Indies Immigration Service has one Internal Affairs Inspector, 14 (fourteen) Immigration Offices, and 2 (two) Immigration Offices overseas. Initially the organizational structure of the Immigration Bureau at the central level and the Immigration Service consisted of a landing and return permit section, a departure, return and passport section, a visa section and a residence section.

b) Staatblad Indonesia No. 332 of 1949

Regulates residence, entry permit, landing of foreigners and shows places of ports, landings, both sea and air. Then on December 27, 1949 it was marked by the recognition of the sovereignty of the Republic of Indonesia, officially the establishment of the RIS Immigration Service, the appointment of the immigration apparatus who was the first to be an Indonesian, namely: Mr. Joesoef Adiwinata, with the Decree of the Minister of Justice of the Republic of Indonesia NO. JZ./30/16 Date 28 January 1950 which was retroactive from 26 January 1950.

c) In 1950

As a newly independent nation and still in an upheaval, of course the facilities and infrastructure to support the Immigration Service for the first time were held by an indigenous son, namely Mr. H.J Adiwinata and the composition of the immigration service under the coordination of the Minister of Justice. The products of legislation in the field of Immigration during the RIS administration were ${ }^{56}$ :

1) Decree of the Minister of Justice Number JZ / 239/12 dated 12 July 1950 regarding the reporting of passengers to customs leaders when they land at a port that has not been officially designated as a landing port

56 Directorate of Immigration, Sejarah Direktorat Jenderal Imigrasi, http://www.imigrasi.go.id/index.php/profil/sejarah\#\%E2\%80\%A2-era-revolusikemerdekaan, accessed on 19 February 2019. 
2) RIS Emergency Law Number 40 of 1950 concerning RI Travel Documents

3) RIS Emergency Law Number 42 of 1950 concerning Immigration Fees.

\subsection{Year 1950-1959}

Immigration Head Office at the central level is under the Minister of Justice who is assisted by two representatives, namely Head of Immigration Office Bureau I and II. The impact of the immigration policy of the Dutch East Indies Government with this opendour politiek resulted in various ethnicities from various continents coming and living in Indonesia, so that their citizenship status had disappeared. To curb and find out the number of immigrants issued Government Regulation Number 32 of 1954 concerning the Registration of Foreigners on 20 April 1954.

\subsection{Year 1959-1966}

After the Presidential Decree dated July 5, 1959 in the Decree of the Minister of Justice Number JS4/4/February 16, 1969 concerning Organizational Tasks of the Ministry of Justice, the term Jawatan was changed to a Directorate headed by the Head of the Directorate and assisted by a representative. Presidential Decree Number 144 of 1964 dated 6 June 1964 in Article 2 states that the technical operational and administrative Directorate of Immigration of the Republic of Indonesia is under the Working Cabinet Presidium. This was in effect until August 31, 1966.

\subsection{Year 1966-1974}

Cabinet Presidium Decree Number 75/U/KEP/11/1966 concerning Organizational Structure and Division of Departmental Duties. The Directorate of Immigration is again under the Ministry of Justice under the name of the Directorate General of Immigration which consists of the Director General of Immigration, the Secretary of the Director General of Immigration, the Directorate of General Immigration, the Directorate of Foreign Supervision, the Directorate of Supervision of Services and the Immigration Office in the regions.

\subsection{Year 1974-1985}

Presidential Decree Number 44 of 1974 concerning the Organizational Structure of the Ministry revokes the Cabinet Presiduim Decree Number 75 / U / KEP / 8/1966, in Article 9 of Presidential Decree Number 45 of 1974 the Directorate General of Immigration consists of the Secretariat of the Directorate General, the Directorate of Interstate Traffic and 
Licensing, Directorate of Foreigner Status Control and Directorate of Immigration Tracking. Presidential Decree No. 45/1974 was finally repealed by Presidential Decree No. 15/1984 concerning the Organizational Structure of Departments consisting of the Secretariat of the Directorate General, the Directorate of Transnational Transnational and Licensing, the Directorate of Control of Foreign Status, the Directorate of Supervision and Prevention and the Directorate of Immigration Activities Tracking.

\subsection{Year 1992-2011}

Since the enactment of Law No. 9 of 1992 concerning Immigration, on March 31, 1992 there has been a new era in the immigration law system, because immigration politics that are juridically selective are spelled out in one legal provision that applies nationally. Since then, all immigration laws and regulations are united in the form of Law, namely Law No. 9 of 1992 which replaced several previous regulations, namely ${ }^{57}$ :

a. Toelatingsbesluit (S. 1961 No. 47)

b. Toelatingsbesluit (S. 1949 No. 331)

c. Law No. 42 Drt. 1950 concerning Immigration Fees

d. Law No. 9 Drt. 1950 concerning Supervision of Foreigners

e. Law No. 8 Drt. 1955 concerning Immigration Criminal Action

f. Law No. 9 Drt. 1955 concerning the Population of Foreigners; and

g. Law No. 14 Drt. 1959 on Indonesian travel documents

As for the next main issue is whether selective legal politics was actually implemented after the issuance of Law Number 9 of 1992 concerning Immigration, because it also coincided with the enactment of the visa-free policy which was given gradually to 48 countries issued since the year 1983, which caused the politics of immigration to be open again. ${ }^{58}$

Even so, it must still be recognized that Law Number 9 of 1992 concerning Immigration has served as an umbrella for the implementation of immigration duties. The modification of this Law is designed with a different spirit and spirit from time to time which emphasizes more on national interests and greater protection for Indonesian citizens. ${ }^{59}$

\subsection{Year 2011 to present period}

Basically, the presence of Law no. 6 of 2011 concerning Immigration in principle, does not change much of the legal politics of Law No. 9 of 1992 concerning Immigration, for example ${ }^{60}$ :

57 Jazim Hamidi dan Charles Christian, Hukum Keimigrasian Bagi Orang Asing di Indonesia, Jakarta, Sinar Grafika, 2016, pp. 22-23.

58 Ibid.

59 Ibid.

60 Ibid., p. 24. 
a. Law Number 6 of 2011 concerning Immigration has regulated the expansion of the subject of criminal offenders, to include corporations.

b. The existence of Immigration Intelligence which was previously in Law No. 9 of 1992 concerning Immigration has not been regulated.

c. The existence of a regulation on the management information system of the Directorate General of Immigration

d. Regulations related to the Statement of Integration in Article 1 number 22 of Law Number 6 Year 2011 concerning Immigration, the Statement of Integration is a statement by foreigners to the Government of the Republic of Indonesia as one of the conditions for obtaining a Permanent Residence Permit.

e. Regulations related to Guarantor in Article 1 number 26 Law Number 6 Year 2011 concerning Immigration which explains that Guarantor is a person or corporation that is responsible for the existence and activities of foreigners while in the Indonesian Territory.

f. There is a limitation on the detention period for a foreigner at the Immigration Detention Center, which was never regulated in the previous law, but the maximum detention period is set for 10 (ten) years as stipulated in Article 85 paragraph (2).

g. Regarding prevention in Article 97 paragraph (1), it says that prevention can be extended every 6 (six) months and there is no set limit on the maximum number of such extensions. For this article, Prof. Yusril Ihza Mahendra went to the Constitutional Court and the Constitutional Court granted his lawsuit in accordance with the Decree of the Constitutional Court No. 64 / PUU-IX / 2011 dated June 20, 2012. Thus, the decision to prevent a person is only enforced 2 (two) times. Unlike before, it can be extended every 6 (six) months with an unlimited number of extensions.

h. The regulation in Article 1 number 32 is related to Human Smuggling

i. Article 86 Paragraph 1 of Law Number 6 Year 2011 concerning Immigration related to the provisions of Immigration Administrative sanctions are not enforced against victims of trafficking and human smuggling.

The immigration function which has a multidimensional and interdisciplinary nature coupled with a very dynamic human nature and global development of the world, especially increasing migratory flows transnationally, so in the future not a single country in the world will be spared from the problem of immigration. The Indonesian government must 
be precise and immediate to be able to anticipate this, among others, with developments in the world of international migration.

As a concrete example, for example in Article 1 of Law Number 6 Year 2011 concerning Immigration it states that: Immigration is a matter of the traffic of people entering or leaving Indonesian territory as well as supervision in order to uphold the upholding of State sovereignty. The understanding that this point only provides a definition of human traffic and its guardians who enter and exit the territory of Indonesia, even though currently the immigration paradigm has changed a lot which when we refer to current international understandings, that the notion of immigration is no longer merely focused on humans as objects that traffic between countries and their supervision. The new paradigm has shifted and provided an extension of the notion of migration which was previously only the meaning of movement from one country to another, and was carried out individually, but now this definition has stated that migration is not only to one country but is assumed to be carried out in several countries (transnational migration) and carried out in groups. ${ }^{6}$

Immigration literature in the last five years which is used as a reference to provide an explanation of these changes, which explains that a migration process from humans (human migration) does not only see humans unsich but must be understood that every movement or movement of humans Simultaneously it also means the movement or transfer of money capital, human resources (human capital), political, social, cultural, security, demographic, environmental and other aspects of life. ${ }^{62}$

\section{b) Development of Immigration Crimes in Indonesia}

To understand the formulation of criminal sanctions in Law Number 6 of 2011 concerning Immigration, below will describe the formulation of each article in the Immigration Law, as explained on Table 3.

\section{Table 3. Formulation of Crime in Law Number 6 of 2011 concerning Immigration}

\begin{tabular}{ccl}
\hline No & Article & Forms of Prohibited Actions \\
\hline 1 & 113 & $\begin{array}{l}\text { Entering or leaving the Indonesian Territory that is not subject to } \\
\text { inspection by Immigration Officers at Immigration Checkpoints. }\end{array}$ \\
\hline 2 & 114 & $\begin{array}{l}\text { (1) } \begin{array}{l}\text { Transport equipment that enters or leaves the Indonesian } \\
\text { Territory by means of transportation that does not pass } \\
\text { through the Immigration Checkpoint. }\end{array} \\
\end{array}$ \\
\hline
\end{tabular}

${ }^{61}$ Ibid., p. 27

62 Ibid. 


\begin{tabular}{|c|c|c|}
\hline & & $\begin{array}{l}\text { (2) Transport equipment intentionally disembarking or loading } \\
\text { passengers who do not go through the inspection of the } \\
\text { Immigration Officer or the landing inspection officer at the } \\
\text { Immigration Checkpoint }\end{array}$ \\
\hline 3 & 115 & $\begin{array}{l}\text { Transportation means that do not pay load fees as referred to in } \\
\text { Article } 19 \text { paragraph (4) (the person in charge of the } \\
\text { Transportation Tool is obliged to check Travel Documents and / or } \\
\text { Visas for each passenger who will travel) and Article } 79 \text {. }\end{array}$ \\
\hline 4 & 116 & Failure to carry out its obligations as referred to in Article 71. \\
\hline 5 & 117 & $\begin{array}{l}\text { Do not provide information or do not provide data on foreigners } \\
\text { staying at their home or lodging after being asked by the } \\
\text { immigration official on duty }\end{array}$ \\
\hline 6 & 118 & $\begin{array}{l}\text { Providing information that is not true or does not fulfill the } \\
\text { guarantees it provides as referred to in Article } 63 \text { paragraph (2) } \\
\text { and paragraph (3). }\end{array}$ \\
\hline 7 & 119 & $\begin{array}{l}\text { (1) Entering and / or being in the Indonesian Territory that does } \\
\text { not have a valid Travel Document and Visa. } \\
\text { (2) Using Travel Documents, but it is known or reasonably } \\
\text { suspected that the Travel Documents are fake or falsified }\end{array}$ \\
\hline 8 & 120 & $\begin{array}{l}\text { (1) Doing an act that is aimed at seeking profit, either directly or } \\
\text { indirectly, for oneself or another by bringing a person or group } \\
\text { of people, whether organized or not, or ordering other people to } \\
\text { bring someone or a group of people who do not have the right } \\
\text { to enter the Indonesian Territory legally, using either legal or } \\
\text { fake documents, or without using travel documents, whether } \\
\text { through immigration checks or not. } \\
\text { (2) Attempt to carry out Human Smuggling as referred to in } \\
\text { paragraph } 1 \text {. }\end{array}$ \\
\hline 9 & 121 & $\begin{array}{l}\text { (a) Making fake or falsifying Visas or Signs of Entry or Stay } \\
\text { Permits with the intention of being used by himself or others } \\
\text { to enter or leave Indonesian territory. } \\
\text { (b) Using a fake or falsified Visa or Entry Sign or Residence } \\
\text { Permit to enter or exit or be in the Indonesian Territory. }\end{array}$ \\
\hline 10 & 122 & $\begin{array}{l}\text { (a) Abusing or engaging in activities that are inconsistent with } \\
\text { the purpose and purpose of the residence permit granted to } \\
\text { him. } \\
\text { (b) Ordering or giving opportunities to foreigners to abuse or carry } \\
\text { out activities that are inconsistent with the purpose or purpose } \\
\text { of granting the Stay Permit granted to them. }\end{array}$ \\
\hline 11 & 123 & $\begin{array}{l}\text { (a) Providing false or falsified letters or data or false information } \\
\text { with the intention of obtaining a Visa or Residence Permit for } \\
\text { himself or another person. } \\
\text { (b) Using a Visa or Stay Permit as referred to in letter a to enter } \\
\text { and / or exit and / or be in the Indonesian Territory. }\end{array}$ \\
\hline 12 & 124 & $\begin{array}{l}\text { (a) Conceal or protect or provide lodging or provide a living or } \\
\text { provide employment to foreigners who are known or } \\
\text { reasonably suspected to be in the Territory of Indonesia } \\
\text { illegally }\end{array}$ \\
\hline
\end{tabular}


(b) The residence permit expires.

$13 \quad 125 \quad$ Without a license to be in certain areas that have been declared prohibited for foreigners as referred to in Article 48 paragraph (4).

c) Typical Characteristics of Legal Subjects of Law Number 6 of 2011 concerning Immigration

The characteristics of legal subjects in Law Number 6 of 2011 concerning Immigration, highlighted below, and it can be held accountable for enforcing the Immigration law in Indonesia, namely as follows ${ }^{63}$ :

1. Immigration Officers are employees who have gone through special immigration education and have special Immigration expertise and have Immigration technical expertise and have the authority to carry out duties and responsibilities under this Law.

2. Foreigner is a person who is not an Indonesian citizen

3. Corporation is an organized group of people and / or assets, either a legal entity or a non-legal entity.

4. Guarantor is a person or corporation that is responsible for the existence and activities of foreigners while in the Indonesian Territory.

5. Transport means are ships, airplanes or other means of transportation commonly used, either to transport people or goods.

6. Detainers are foreigners who live in the Immigration Detention Center or Immigration Detention Room who have received a detention decision from the Immigration Officer.

7. Person in charge of transportation means the owner, manager, agent, skipper, ship captain, pilot captain or driver of the transportation means concerned.

8. Passenger is any person on board the transportation means.

Above, it has been explained concretely about legal subjects that can be held accountable for violations and crimes in the Immigration Law, starting from foreigners, corporations, people in charge of transportation means and immigration officials who can also be held accountable if they commit crimes or violations in the Immigration Law. The types of crimes are imposed in Law Number 6 of 2011 concerning Immigration, how long is the minimum imprisonment and imprisonment and how many are the minimum to maximum fines in Law Number 6 of 2011 concerning Immigration, explained on Table 4, as follow.

63 Immigration Law

Indonesian Journal of Advocacy and Legal Services, Vol. 2 No. 2 (2020) 155 
Table 4. Types of Sanctions in Indonesian Immigration Law

\begin{tabular}{|c|c|c|}
\hline \multicolumn{3}{|c|}{ TYPE OF SANCTIONS } \\
\hline Imprisonment & Confinement & Fines \\
\hline & $\begin{array}{l}\text { Articles } 116,117,124 \text { letter } \\
\text { (b) The maximum } \\
\text { imprisonment is } 3 \text { months }\end{array}$ & $\begin{array}{l}\text { The maximum fine is } \mathrm{Rp} \text {. } \\
25,000,000.00 \text { (twentyfive } \\
\text { million rupiah). }\end{array}$ \\
\hline $\begin{array}{l}\text { Article } 113 \text { in conjunction } \\
\text { with Article } 114 \text {, paragraph } \\
\text { (1), } 115 \text {, The maximum } \\
\text { imprisonment is } 1 \text { year }\end{array}$ & & $\begin{array}{l}\text { Criminal A maximum fine } \\
\text { of Rp. 100,000,000 (one } \\
\text { hundred million rupiah). }\end{array}$ \\
\hline $\begin{array}{l}\text { Article } 114 \text { paragraph }(2) \text {, } \\
124 \text { letter a, } 130 \text {, the } \\
\text { maximum imprisonment is } \\
2 \text { (two) years }\end{array}$ & & $\begin{array}{l}\text { The maximum fine is } \mathrm{Rp} \text {. } \\
200,000,000.00 \text { (two } \\
\text { hundred million rupiah). }\end{array}$ \\
\hline $\begin{array}{l}\text { Article } 125, \text { The maximum } \\
\text { imprisonment is } 3 \text { years }\end{array}$ & & $\begin{array}{l}\text { The penalty is Rp. } \\
300,000,000.00 \text { (three } \\
\text { hundred million rupiah). }\end{array}$ \\
\hline $\begin{array}{l}\text { Articles } 118,119 \\
\text { paragraphs }(1) \text { and }(2), \\
121,122,123,126,127,128, \\
129,131,135, \text { the } \\
\text { maximum imprisonment is } \\
5 \text { years }\end{array}$ & & $\begin{array}{l}\text { The maximum fine is } \mathrm{Rp} \text {. } \\
500,000,000.00 \text { (five } \\
\text { hundred million rupiah). }\end{array}$ \\
\hline $\begin{array}{l}\text { Article } 120 \text {, imprisonment } \\
\text { for a minimum of } 5 \text { (five) } \\
\text { years and a maximum of } 15 \\
\text { years }\end{array}$ & & $\begin{array}{l}\text { The punishment shall be a } \\
\text { minimum fine of Rp. } \\
500,000,000.00 \text { (five } \\
\text { hundred million rupiah) } \\
\text { and a maximum of Rp. } \\
1,500,000,000.00 \text { (one } \\
\text { billion five hundred million } \\
\text { rupiah). }\end{array}$ \\
\hline
\end{tabular}

\begin{tabular}{l}
\hline Article 132 , imprisonment \\
for a maximum of 7 years. \\
\hline Article 133 (a), (b), the \\
maximum imprisonment is \\
5 years. \\
\hline Article 133 (c), (d), the \\
maximum imprisonment is \\
2 years. \\
\hline Article 133 (e), the \\
maximum imprisonment is \\
6 months. \\
\hline Article 134 (a), the \\
maximum imprisonment is \\
3 years. \\
\hline Article 134 (b), The \\
punishment is 5 years \\
imprisonment. \\
\hline Article 136 paragraph (1), \\
Crime is imposed on the \\
management and the \\
corporation. \\
\hline Article 136 paragraph $(2)$
\end{tabular}


Imposition of punishment

against corporations is only

a fine, provided that the

amount is 3 times the

penalty in paragraph (1).

In Law Number 6 of 2011 concerning Immigration, criminal sanctions can be in the form of imprisonment, confinement, and fines. The imprisonment for a minimum of 1 year is contained in Article 113, Article 114, paragraph (1) jo Article 115 and the maximum imprisonment of 15 years is contained in Article 120 of the Immigration Law concerning the prohibition of bringing a person or group of people, either in an organized or unorganized manner., or ordering other people to bring a person or group of people who do not have the right to enter Indonesian territory legally, using either legal or fake documents, or without using travel documents, whether through immigration checks or not or attempts to carry out human smuggling.

A maximum fine of Rp. 1,500,000,000.00 (one billion five hundred million rupiah). The lightest fines with imprisonment for a maximum of 3 months are contained in Articles 116, 117, 124 letters (b) and the minimum fine is Rp. 25,000,000.00 (twentyfive million rupiah).

Basically, foreigners who violate Law Number 6 of 2011 concerning Immigration, whether they are subject to administrative or criminal sanctions, will eventually be subject to deportation.

\section{Immigration Law Enforcement Arrangements: The Influencing Factors}

In enforcing the Immigration law, Immigration Officers can supervise foreigners according to Law Number 6 of 2011 concerning Immigration in Article 66 to Article 73 and more specifically regulated in Government Regulation Number 31 of 2013 concerning the Rules for Implementing the Immigration Law.

In law enforcement, there are factors that influence law enforcement itself. According to Soerjono Soekanto, law enforcement does not merely mean the implementation of laws, although in reality in Indonesia the tendency is so, so that the notion of law enforcement is so popular, besides that there is a strong tendency to interpret law enforcement as the implementation of judges' decisions. ${ }^{64}$

64 Soerjono Soekanto, Faktor-faktor yang Mempengaruhi Penegakan Hukum, Jakarta, PT Raja Grafindo Persada, 2014, pp. 7-8. 
The main problem of law enforcement lies in the factors that might influence it. These factors have a neutral meaning, so that the positive or negative impact lies in the contents of these factors as follows ${ }^{65}$ :

1) The legal factor itself, which in this case is the law

2) Law enforcement factors, namely parties directly involved in the field of law enforcement, which includes not only law enforcement, but also peace maintenance

3) Facility factors or facilities that support law enforcement, including human resources who are educated and skilled, good organization, adequate equipment, sufficient finance and so on. If these things are not fulfilled, then it is impossible for law enforcement to achieve its objectives

4) Community factors, namely the environment in which the law applies or is applied. Law enforcement comes from society, and aims to achieve peace in society; and

5) Cultural factors, as a result of work, creativity, and taste based on human initiative in social life. Legal culture (system) basically includes the values that underlie applicable law, values which are abstract conceptions of what is considered good (so that it is followed) and what is considered bad (so that it is avoided).

Based on the interview with Mr. Jaya Saputra, it was explained that the factors that influence immigration law enforcement include 66 :

1) The legal factors are:

a. The lack of clarity in the Immigration Law which regulates how to implement Administrative Actions and Criminal Sanctions in the event of violations and crimes in Law Number 6 of 2011 concerning Immigration. Because in Law No. 6 of 2011 on Immigration, the application of administrative sanctions can be applied to all types of law violations in Law No. 6 of 2011 on Immigration, except for victims of trafficking and people smuggling. In addition, foreigners who commit immigration violations or crimes will be included in the Immigration Detention Center while being processed in the criminal justice system, after undergoing the Criminal Justice System process the convicted person will be in detention again and then will be deported.

b. Lack of synergy between national and international institutions such as UNHCR for law enforcement for foreigners who enter illegally, but claim to be asylum seekers, Immigration Officials should coordinate

65 Ibid.

66 Results of Interview with Mr. Jaya Saputra, S.H, as Head of Sub Directorate of Immigration and Deportation Detention, December 17, 2018. 
with UNHCR to find out whether the foreigner is considered as an asylum seeker or not, when This Foreigner declares himself an Asylum Seeker, so the Foreigner will receive a Refugee Certificate which is a very long process without any time limit on how long the Certificate from UNHCR can be issued.

c. he maximum detention limit for 10 years is considered too long which has the potential to make full the Immigration Detention Center.

d. After March 15, 2018, part of International for Migration (IOM) assistance to the Indonesian government was stopped so that there was a shortage of budget for enforcement of the Immigration law.

2) The law enforcement factors include:

a. Foreigners with sufficient finances when committing violations and crimes in Law Number 6 of 2011 concerning Immigration will use a lawyer to split up their clients and this tends to hinder the legal process at Immigration because lawyers try to bribe Immigration PPNS so that the case can be resolved at outside the legal process.

b. The United Nations High Commissioner For Refugees (UNHCR) easily grants status to foreign nationals seeking asylum, for example Nigerian citizens entering Indonesia legally into Indonesia then deliberately dispose of their citizens' documents and complain to the United Nations High Commissioner For Refugees (UNHCR)) to seek asylum, after being granted asylum seeker status, they will stay in Indonesia indefinitely.

In addition to the factors above, of course immigration innovation is also a determining factor for the success of law enforcement in Indonesia, Immigration Innovation in Indonesia can vary depending on each region, but in general these innovations are as follows ${ }^{67}$ :

1. Expansion of providing electronic passports at 18 immigration offices with the aim of providing certainty of service to applicants.

2. The Directorate General of Immigration simplifies licensing for foreign workers through the One Single Submission (OSS) service in collaboration with the Ministry of Manpower. So, as to produce a very simple and efficient process in response to the direction of the President of the Republic of Indonesia to the Immigration ranks.

3. Implementation of the QR Code system at 5 immigration checkpoints, the QR Code used is an effort to improve the facilities and infrastructure used

67 Dylan Aprialdo Rachman, "Menkumham Puji 6 Terobosan Ditjen Imigrasi", https://nasional.kompas.com/read/2019/01/28/10063631/menkumham-puji-6-terobosanditjen-imigrasi, accessed on 2 April 2019 
by Immigration officials in carrying out the surveillance process in the field,

4. Facilitating residence permits for foreign investors who wish to invest in Indonesia.

5. The Class II Karawang Immigration Office made a new breakthrough by making the Indonesian Immigration Mobile Book (immobook) application. This is to make it easier for the public to access information, from service procedures to immigration regulations to public services. People only need to download this application using a smartphone.

6. Immigration service means that there is a maximum time certainty of 1 hour for people who will make passports, also the Foreigner Mapping System (Sistapora) 68

7. The Online Visa Application assists foreigners in obtaining a Visa Approval Letter as the basis for Indonesian representatives abroad to issue visas for foreigners. ${ }^{69}$

8. Online Residence Permit applications began to be applied on 19 November 2017 and can be accessed by foreigners applying for a residence permit in Indonesia. ${ }^{70}$

9. Applications for services but also supervision of foreigners living in Indonesia. People who know the presence of strangers in the vicinity, whether at the inn or at home, can report through the Foreigner Reporting Application at the address apoa.imigration.go.id/poa. People who own hotels, inns, or individuals, please report the whereabouts of foreigners through APOA Directorate General of Immigration. Jadia assists officers in recording foreigners living in Indonesia. ${ }^{71}$

According to Dilan, that Criminal Sanctions certainly require costs and a long time as well as a convoluted bureaucratic process, ideally using Administrative Sanctions Measures as a practical effort and is still in the corridor of immigration law enforcement, because Immigration Administrative Actions can have quite a good effect. with a fast process by

68 Terobosan Imigrasi Depok Dinilai Kreatif, http://mediaindonesia.com/read/detail/53770terobosan-imigrasi-depok-dinilai-kreatif, accessed on 2 April 2019

69 Dirjen Imigrasi RI, Imigrasi Luncurkan Inovasi Layanan Keimigrasian Berbasis Teknologi Informasi, http://www.imigrasi.go.id/index.php/en/berita/berita-utama/1499imigrasi-luncurkan-inovasi-layanan-keimigrasian-berbasis-teknologi-informasi, accessed on 2 April 2019

70 Ibid.

71 Ibid. 
carrying out Deportation ${ }^{72}$ and putting the foreigner on the blacklist ${ }^{73}$ so that the person can no longer enter the Indonesian Territory. Regarding the handling of immigration violations and crimes, whether to use criminal sanctions or Immigration Administrative Sanctions, all are submitted to the Immigration Officer Discretion to determine it. ${ }^{74}$

When immigration will give administrative sanctions in the form of deportation to foreigners who do not carry official documents when entering the territory of Indonesia. If there are foreigners as asylum seekers, they will be offered by the immigration authorities whether to be repatriated or remain in Indonesia, or be placed in a third country such as Australia, Canada, etc. If you have special skills, it will be an added value to be able to work in a third country. For example, in Malaysia, the IDPs can work in oil palm plantations etc. 75

Meanwhile, according to Komang, that enforcement of the Immigration law sometimes experiences obstacles due to lawyers who complicate the immigration legal process who want to resolve cases outside the legal process and for sanctions that are often applied is Deporatation. ${ }^{76}$

From the explanation above related to the factors that influence law enforcement above, the author argues that the factor of law enforcement in the Immigration Law occurs in the dimension of its own legal factors, which in this case is the law where the application of criminal sanctions and administrative sanctions fully submitted to Immigration Officials, law enforcement factors, namely parties who are directly involved in the field of law enforcement which not only includes law enforcement, but also peace maintenance, in terms of advocates also becomes an obstacle in enforcing the Immigration law, and lack of coordination with international institutions such as UNHCR for the affairs of foreigners who claim to seek asylum when entering Indonesia without bringing legal documents. Immigration officials have not been able to impose legal sanctions before the confirmation of the status of UNHCR.

72 Article 1 point 36 of Immigration Law emphasized that Deportation is the act of forcibly removing foreigners from Indonesian territory.)

73 Article 1 point 29 states, deterrence is a prohibition against foreigners from entering Indonesian territory based on reasons of immigration. (See Indonesia, Law Number 6 Year 2011 Concerning Immigration, State Gazette of the Republic of Indonesia, Year 2011, Number 52)

74 Results of an interview with Mr. Dilan, as the Head of the Sub-directorate for Immigration Enforcement on January 29, 2019.

75 Ibid.

76 Results of an interview with Mr. Komang as Head of Subag of the Directorate of Immigration Investigation of the Republic of Indonesia, on January 29, 2019. 


\section{Application of Ultimum Remedium Principle in Immigration} Crime

a) Nature of the Ultimum Remedium Principle

The principle of ultimum remedium was first used by the Dutch Minister of Justice, namely Mr. Modderman in front of the Parliament of the Netherlands, in response to a statement by one of the MPs, Mr. Mackay, who said that he has failed to find a legal basis regarding the need for a punishment for someone who has committed an offense. Minister Modderman said that ${ }^{77}$ :

"Ik geloof dat dit beginsel niet alleen voortduren tusschen de regels te lezen is, maar ook herhaaldelijk, misshien in een anderen vorm wordt uitgesproken. Het beginsel is dit: dat alleen datgene mag gestraft worden, wat in de eerste plaats onregt is. Dit is eene condition sine qua non. In de tweede plaats komt de eisch er bij dat het een onregt zij, waarvan de ervaring heft geleerd dat her door gene andere middle behoorlijik is te bedwingen. De straf moet blijven een ultimum remedium. Uit den aard der zaak zijin aan elke strafbedreiging bezwaren verbonden. Lader verstanding mensch kan di took zonder toelichting wel begrijpen. Dat wil niet zeggen dat men de strafbaarstelling achterwege moet laten, maar weld at men steeds tegenover elkander moet wegen de voordelen en de nadelen van de strafbaarstelling, en toezien dat niet de straf worde een geneesmiddel erger dan den kwal."

I believe that this principle can not only always be read in regulations, but also repeatedly pronounced, although it may be in other forms. This principle is that what is punishable is first of all violations of the law, which according to experience cannot be done away with by other means. This punishment should be a last resort. Basically, there are objections to every threat of punishment. However, this does not mean that we should ignore the determination of when a person can be punished, but it is true that there one has to make judgments about the advantages and disadvantages and must keep the punishment really a curative effort and not make the disease worse.

Andi Zainal Abidin also emphasized that ultimum remedium is the last attempt to improve human behavior, especially criminals, and provide psychology so that other people do not commit crimes. Criminal law must be an ultimum remedium because the Criminal Procedure Code gives too much

77 Smidt, Geschiedenis Van Het Wetboek Van Strafrecht 1891-1892 dan 1900-1901. Harlem, p. 17, as cited by P.A.F Lamintang, Dasar-Dasar Hukum Pidana Indonesia, Bandung, PT. Citra Aditya Bakti, 1997, pp. 16-17. 
power to the Police, Public Prosecutors and Judges. ${ }^{78}$ In line with Abidin, Van Bemmalen stated that ultimum remedium has its own place among other laws and must be interpreted as an effort (middel), not as a tool to restore injustice or recover losses, but an effort to restore an uneasy situation in society, which if not done something against that injustice can cause people to take justice into their own hands. ${ }^{79}$

If the National Law System and the National Criminal Law System have been realized, then the next step is to restore the function of criminal sanctions as ultimum remedium. Violation of the law always results in the imposition of sanctions, but the conditions to be developed later concern the question whether it should be in the form of criminal sanctions? If a criminal sanction has been imposed, should it be in the form of a criminal sanction of deprivation of liberty? Is there no other way to carry out the crime of deprivation of liberty?

It has been said that the applicable criminal law system is a legacy of the classical tradition which views criminal sanctions as retaliation or compensation for someone for their actions that violate the norms of criminal law. In the national law system and national criminal law system that will be formed, a new paradigm must be developed which is characterized by modern or even Neo Classical sects which view that criminal sanctions are the last tool, as well as criminal sanctions for deprivation of liberty as the last resort. Therefore, it is necessary to build a more modern system of criminal sanctions in accordance with the development of social science and humanities. ${ }^{80}$

If the aspects of justice and benefit take precedence over legal certainty, it means that consciously we have made social welfare the goal of punishment. Muladi said that the Criminal Justice System in the short term aims to conduct resocialization of criminal offenders, medium term in the form of crime control and long term in the form of social welfare.

In line with Romli Atmasasmita's opinion which stated that the founder of the Republic of Indonesia was not without the aim of forming the 1945 Constitution, in addition to forming a framework of thought on the basis of a rule of law, he had also thought deeply about the leitmotive and vision of Indonesian law that could create the welfare of the Indonesian nation. The failure to achieve this is due to a lack of understanding of the past criminal law makers, who are still guided by criminal events that have occurred (ex

78 Andi Zainal Abidin, Asas-Asas Hukum Pidana Bagian Pertama, Bandung, Alumni, 1987, p. 16.

79 Van Bemmelen, Ons Strafrecht I Algemeen Deel Het Materiele Strafrecht, Groningenz: H.D Tjeenk Willink, 1971, p. 17, as cited by Buku P.A.F Lamintang, Op.Cit., p. 17.

80 Muladi, Kapita Selekta Sistem Peradilan Pidana, Semarang, Badan Penerbit UNDIP, pp. 75-76. 


\section{A. Bahari}

ante), but have not considered the impact of these criminal events by using the principle of maximization, efficiency, and balance (equilibrium). The next consideration is empirical, namely that law enforcers are still based on the parameters of success (output) not based on the parameters of the usefulness of the work of criminal law (outcome). ${ }^{81}$

Based on the above view, it means that there is a meeting point between criminal policies, namely policies or politics to use Criminal Law in an effort to tackle crime with national development policies to bring prosperity. However, it must be realized that if the use of criminal sanctions is not carried out carefully and cautiously, it will lead to injustice or unfairness. Because what is promised by the criminal law sometimes creates a condition that is unwelfare. The nature of unwelfare can take the form of prisonisation, stigmatization and recidivism and individually the punishment imposed can lower human dignity. ${ }^{82}$

With the principle of ultimum remedium as stated above, unwelfare can be avoided. Criminal is only imposed in an urgent situation because there are no other measures that can ensure that norms are upheld. With a note that the application of criminal sanctions still observes the principle of subsidarity, meaning that the judge tries to impose the most lenient criminal sanctions among the available alternatives. ${ }^{83}$

With the principle of ultimum remedium, it is hoped that it can avoid unwelfare in the law enforcement process. Criminal is only imposed in an urgent situation because no other effort can guarantee that norms are upheld. With a note that the application of criminal sanctions still observes the principle of subsidarity, meaning that the judge tries to impose the most lenient criminal sanctions among the available alternatives. The provisions of the positive law of the ius constitutum should be animated by the ideal law or the law that the ius constituendum aspires to. However, in the event that both are not possible, the judge can determine concrete law in concreto in the form of law that applies in fact or in certain cases ius operatum. ${ }^{84}$

In line with Sudarto's opinion that crime can be viewed from three aspects, namely 85 :

1. Criminal law which we aspire to or criminal law as ius constituendum

81 Romli Atmasasmita, Op.Cit., pp. 1-3.

82 Ali Zaidan, Op.Cit., p. 215.

83 Ibid., p. 216.

84 Ibid.

85 Sudarto, Hukum Pidana Dan Perkembangan Masyarakat, Bandung, Sinar Baru, 1983, p. 31. 
2. Criminal law that is currently in force, means that which must be applied by the judiciary, or what is called criminal law as the ius constitutum or ius operandum; and

3. Criminal law which is actually applied to a concrete act, or criminal law as ius operatum. In this connection, the effect referred to is related to the formation of criminal laws, the Criminal Code and the current criminal law regulations, and the issuance of decisions in criminal cases.

One of the causes of the decline in law enforcement so that marginalized people are processed in court is more due to errors in interpreting the principles of law to be enforced. As a result, the nature of ultimum remedium consciously changes to premium remedium because there is a belief that against violations of social norms, Criminal Law is a guarantor so that norms are obeyed. Without realizing it, the misapplication of the use of this principle has returned the progress of Criminal Law to the classical direction which uses the means of Criminal Law according to the principle of The Suspect of Law, criminal law is used to convict people suspected of threatening the existence of the Authority. ${ }^{86}$

There are several views from the results of the author's interview regarding the extent to which the application of the ultimum remedium principle in Law Number 6 of 2011 concerning Immigration which regulates the application of administrative sanctions and criminal sanctions. According to Ziko Nunius Fernando, that in order to measure the extent to which administrative sanctions and criminal sanctions are applied, it must be seen from the impact of the violations caused whether it is disturbing to the public or not. If this does not bother the public, then administrative measures will be sufficient without criminal sanctions. 87

According to the Head of the Sub Directorate of Immigration Investigation, Komang, the immigration administrative sanctions in the form of deportation and deterrence are carried out so that foreigners can no longer enter Indonesia, this is the best solution to reduce the number of residents in Correctional Institutions (Lapas), Overcrowded Immigration Detention Centers (Rudenim) and to reduce the use of the State budget for the Immigration case process in the Criminal Justice System. 88

86 Ali Zaidan, Op.Cit., p. 354.

87 Results of an interview with Ziko Nunius Fernando, S.H., M.H., CIL, as an Academician from Palembang University, on February 21, 2019.

88 Results of an interview with Mr. Komang as Head of Subag of the Directorate of Immigration Investigation of the Republic of Indonesia, on January 29, 2019. 


\section{A. Bahari}

\section{b) Data of Offenders of Immigration Crimes}

To find out how to apply the ultimum remedium principle, below will be presented a table regarding the number of foreigners who are subject to criminal sanctions and administrative sanctions in Law Number 6 of 2011 concerning Immigration, from 31 December 2016 to 30 June 2018 throughout Indonesia.

Table 5. Data on Criminal Sanctions in Law Number 6 of 2011 concerning Immigration, from 31 December 2016 to 30 June 2018 throughout Indonesia

\begin{tabular}{|c|c|c|c|c|c|c|}
\hline Article & Form of Action & Sanction & 2016 & 2017 & 2018 & Total \\
\hline & $\begin{array}{l}\text { Anyone who } \\
\text { deliberately enters } \\
\text { or leaves the } \\
\text { Indonesian } \\
\text { Territory who does } \\
\text { not go through the } \\
\text { inspection of the } \\
\text { Immigration Officer } \\
\text { at the Immigration } \\
\text { Checkpoint. The } \\
\text { maximum } \\
\text { imprisonment is } 1 \\
\text { year and / or a } \\
\text { maximum fine of } \\
\text { Rp. 100,000,000 } \\
\text { (one hundred } \\
\text { million rupiah). }\end{array}$ & Criminal & 47 & 10 & 4 & 61 \\
\hline 114 & $\begin{array}{l}\text { (1) Corporations, } \\
\text { carriers of } \\
\text { transportation } \\
\text { means entering or } \\
\text { leaving the } \\
\text { Indonesian } \\
\text { Territory by means } \\
\text { of transportation } \\
\text { that do not pass } \\
\text { through the } \\
\text { Immigration } \\
\text { Checkpoint. The } \\
\text { maximum } \\
\text { imprisonment is } 1 \\
\text { year and / or a } \\
\text { maximum fine of } \\
\text { Rp. 100,000.00.00 } \\
\text { (one hundred } \\
\text { million rupiah). }\end{array}$ & Criminal & 1 & & & 1 \\
\hline 116 & $\begin{array}{l}\text { Foreigner does not } \\
\text { fulfill his } \\
\text { obligations as } \\
\text { referred to in } \\
\text { Article } 71 \text {. The }\end{array}$ & Criminal & 157 & 195 & 70 & 442 \\
\hline
\end{tabular}




\begin{tabular}{|c|c|c|c|c|c|c|}
\hline & $\begin{array}{l}\text { punishment is } \\
\text { imprisonment for a } \\
\text { maximum of } 3 \\
\text { months or a fine of } \\
\text { up to Rp. } \\
25,000,000.00 \\
\text { (twentyfive million } \\
\text { rupiah). }\end{array}$ & & & & & \\
\hline 119 & $\begin{array}{l}\text { (1) Foreigners } \\
\text { Enter and / or are } \\
\text { in the Indonesian } \\
\text { Territory who do } \\
\text { not have valid } \\
\text { Travel Documents } \\
\text { and Visas. The } \\
\text { maximum } \\
\text { imprisonment is } 5 \\
\text { years and a } \\
\text { maximum fine of } \\
\text { Rp. 500,000,000.00 } \\
\text { (five hundred } \\
\text { million rupiah). } \\
\text { (2) Foreigners } \\
\text { Deliberately use } \\
\text { Travel Documents, } \\
\text { but it is known or } \\
\text { reasonably } \\
\text { suspected that the } \\
\text { Travel Documents } \\
\text { are fake or falsified. } \\
\text { The maximum } \\
\text { imprisonment is } 5 \\
\text { years and a } \\
\text { maximum fine of } \\
\text { Rp. } 500,000,000.00 \\
\text { (five hundred } \\
\text { million rupiah). }\end{array}$ & Criminal & 9 & 14 & 14 & 47 \\
\hline 120 & $\begin{array}{l}\text { (1) Every person } \\
\text { commits an act } \\
\text { aimed at seeking } \\
\text { profit, either } \\
\text { directly or } \\
\text { indirectly, for } \\
\text { himself or another } \\
\text { person by bringing } \\
\text { a person or group of } \\
\text { people, whether } \\
\text { organized or } \\
\text { unorganized, or } \\
\text { ordering other } \\
\text { people to bring } \\
\text { someone or a group } \\
\text { of people who are } \\
\text { do not have the }\end{array}$ & Criminal & 1 & 8 & 2 & 13 \\
\hline
\end{tabular}




\begin{tabular}{|c|c|c|c|c|c|c|}
\hline & $\begin{array}{l}\text { right to enter the } \\
\text { Indonesian } \\
\text { Territory legally, } \\
\text { using either legal or } \\
\text { fake documents, or } \\
\text { without using } \\
\text { travel documents, } \\
\text { whether through } \\
\text { immigration checks } \\
\text { or not. Criminal for } \\
\text { human smuggling } \\
\text { with a minimum } \\
\text { imprisonment of } 5 \\
\text { (five) years and a } \\
\text { maximum of } 15 \\
\text { years and a fine of } \\
\text { at least Rp. } \\
500,000,000.00 \text { (five } \\
\text { hundred million } \\
\text { rupiah) and a } \\
\text { maximum of Rp. } \\
1,500,000,000.00 \\
\text { (one billion five } \\
\text { hundred million } \\
\text { rupiah). } \\
\text { (2) Attempt to carry } \\
\text { out human } \\
\text { smuggling as } \\
\text { referred to in } \\
\text { paragraph } 1 . \text { The } \\
\text { punishment is the } \\
\text { same as paragraph } \\
\text { (1). }\end{array}$ & & & & & \\
\hline 121 & $\begin{array}{l}\text { b. Everyone } \\
\text { Deliberately uses a } \\
\text { fake or falsified } \\
\text { Visa or Entry Sign } \\
\text { or Residence Permit } \\
\text { to enter or exit or } \\
\text { be in Indonesian } \\
\text { Territory. } \\
\text { The maximum } \\
\text { imprisonment is } 5 \\
\text { years and a } \\
\text { maximum fine of } \\
\text { Rp. } 500,000,000.00\end{array}$ & & 10 & 1 & & 11 \\
\hline 122 & $\begin{array}{l}\text { a. Any Person or } \\
\text { Foreigner } \\
\text { Intentionally } \\
\text { abuses or carries } \\
\text { out activities that } \\
\text { are not in } \\
\text { accordance with the } \\
\text { intent and purpose } \\
\text { of granting the Stay }\end{array}$ & Criminal & 73 & 23 & 32 & 134 \\
\hline
\end{tabular}




\begin{tabular}{|c|c|c|c|c|c|c|}
\hline & $\begin{array}{l}\text { Permit granted to } \\
\text { him. }\end{array}$ & & & & & \\
\hline & $\begin{array}{l}\text { b. Order or give } \\
\text { opportunities to } \\
\text { foreigners to abuse } \\
\text { or carry out } \\
\text { activities that are } \\
\text { not in accordance } \\
\text { with the intent or } \\
\text { purpose of granting } \\
\text { the Stay Permit } \\
\text { granted to them. } \\
\text { Maximum } \\
\text { imprisonment of } 5 \\
\text { years and a } \\
\text { maximum fine of } \\
\text { Rp. 500,000,000.00 } \\
\text { (five hundred } \\
\text { million rupiah). }\end{array}$ & & 2 & 2 & 2 & \\
\hline 123 & $\begin{array}{l}\text { a. Any person or } \\
\text { foreigner who } \\
\text { deliberately gives } \\
\text { false or falsified } \\
\text { letters or data or } \\
\text { information is not } \\
\text { true with the } \\
\text { intention of } \\
\text { obtaining a visa or } \\
\text { residence permit for } \\
\text { himself or others. }\end{array}$ & Criminal & 4 & 4 & 1 & 9 \\
\hline 124 & $\begin{array}{l}\text { Every Person } \\
\text { Deliberately } \\
\text { conceals or protects } \\
\text { or provides lodging } \\
\text { or provides a living } \\
\text { or gives work to a } \\
\text { stranger who is } \\
\text { known or } \\
\text { reasonably } \\
\text { suspected: } \\
\text { a. Being in the } \\
\text { Territory of } \\
\text { Indonesia illegally } \\
\text { The maximum } \\
\text { imprisonment is } 2 \\
\text { years and / or a } \\
\text { maximum fine of } \\
\text { Rp. } 200,000,000.00 \\
\text { (two hundred } \\
\text { million rupiah). } \\
\text { b. His residence } \\
\text { permit expires } \\
\text { The maximum } \\
\text { imprisonment is } 3 \\
\end{array}$ & Criminal & 7 & 5 & 1 & 13 \\
\hline
\end{tabular}




\begin{tabular}{|c|c|c|c|c|c|c|}
\hline & $\begin{array}{l}\text { months or a } \\
\text { maximum fine of } \\
\text { Rp. } 25,000,000.00 \\
\text { (twentyfive million } \\
\text { rupiah) }\end{array}$ & & & & & \\
\hline 126 & $\begin{array}{l}\text { a. Everyone Uses } \\
\text { RI Travel } \\
\text { Documents to enter } \\
\text { or leave the } \\
\text { Indonesian } \\
\text { Territory, but it is } \\
\text { known or should be } \\
\text { suspected that the } \\
\text { RI Travel } \\
\text { Documents are fake } \\
\text { or falsified. The } \\
\text { maximum } \\
\text { imprisonment is } 5 \\
\text { years and a } \\
\text { maximum fine of } \\
\text { Rp. 500,000,000.00 } \\
\text { (five hundred } \\
\text { million rupiah). } \\
\text { b. Using other } \\
\text { people's RI Travel } \\
\text { Documents or those } \\
\text { that have been } \\
\text { revoked or declared } \\
\text { canceled to enter or } \\
\text { leave the } \\
\text { Indonesian } \\
\text { Territory or } \\
\text { handing over to } \\
\text { other people the RI } \\
\text { Travel Documents } \\
\text { given to them or } \\
\text { belonging to other } \\
\text { people with the } \\
\text { intention of being } \\
\text { used without rights. } \\
\text { The maximum } \\
\text { imprisonment is } 5 \\
\text { years and a } \\
\text { maximum fine of } \\
\text { Rp. } 500,000,000.00 \\
\text { (five hundred } \\
\text { million rupiah). } \\
\text { c. Everyone } \\
\text { Provides invalid } \\
\text { information to } \\
\text { Dotain Travel } \\
\text { Republic of }\end{array}$ & Criminal & 19 & 4 & 15 & 40 \\
\hline
\end{tabular}




\begin{tabular}{|c|c|c|c|c|c|}
\hline & $\begin{array}{l}\text { Indonesia for } \\
\text { himself or others. } \\
\text { The maximum } \\
\text { imprisonment is } 5 \\
\text { years and a } \\
\text { maximum fine of } \\
\text { Rp. } 500,000,000.00 \\
\text { (five hundred } \\
\text { million rupiah). }\end{array}$ & & & & \\
\hline 129 & $\begin{array}{l}\text { a. Everyone } \\
\text { Intentionally and } \\
\text { against the law } \\
\text { makes, owns, keeps } \\
\text { or trades stamps or } \\
\text { other tools that are } \\
\text { used to validate RI } \\
\text { Travel Documents } \\
\text { or other } \\
\text { immigration } \\
\text { documents. The } \\
\text { maximum } \\
\text { imprisonment is } 5 \\
\text { years and a } \\
\text { maximum fine of } \\
\text { Rp. 500,000,000.00 } \\
\text { (five hundred } \\
\text { million rupiah). }\end{array}$ & Criminal & 1 & & 1 \\
\hline 129 & $\begin{array}{l}\text { Everyone } \\
\text { Intentionally and } \\
\text { against the law for } \\
\text { the benefit of } \\
\text { themselves or } \\
\text { others damages, } \\
\text { changes, adds, } \\
\text { reduces, or } \\
\text { removes, partially } \\
\text { or completely, the } \\
\text { information or } \\
\text { stamps contained in } \\
\text { RI Travel } \\
\text { Documents or other } \\
\text { Immigration } \\
\text { Documents. The } \\
\text { maximum } \\
\text { imprisonment is } 5 \\
\text { years and a } \\
\text { maximum fine of } \\
\text { Rp. 500,000,000.00 } \\
\text { (five hundred } \\
\text { million rupiah). }\end{array}$ & Criminal & & 4 & 4 \\
\hline 130 & $\begin{array}{l}\text { Everyone } \\
\text { Deliberately and } \\
\text { unlawfully controls } \\
\text { Travel Documents } \\
\text { or other }\end{array}$ & Criminal & 1 & & 1 \\
\hline
\end{tabular}




\begin{tabular}{l}
\hline \\
Immigration \\
Documents \\
belonging to other \\
people. The \\
maximum \\
imprisonment is 2 \\
years and / or a \\
maximum fine of \\
Rp. 200,000,000.00 \\
(two hundred \\
million rupiah). \\
(1) Corporation In \\
the case of a \\
criminal act as \\
referred to in \\
Article 114, Article \\
116, Article 117, \\
Article 118, Article \\
12o, Article 124, \\
Article 128 and \\
Article 129, it is \\
committed by the \\
corporation. \\
Criminal imposed \\
on the management \\
and the \\
corporation. \\
TOTAL \\
\hline
\end{tabular}

The data above is a criminal sanction imposed by Immigration Officers on offenders in Law Number 6 of 2011 concerning Immigration. From the table above, it can be calculated the number of criminal sanctions imposed by Immigration Officers from 2016 to 2018 as follows:

\section{Table 6. Total Number Criminal Sanctions on Immigaration Cases (2016-2018)}

\begin{tabular}{ccc}
\hline Year & Type of Sanction & Total \\
\hline 2016 & Criminal & 34 \\
2017 & Criminal & 237 \\
2018 & Criminal & 145 \\
\hline \multicolumn{2}{c}{ Total } \\
\hline
\end{tabular}

Based on the data above, it can be concluded that from 2016 to 2018 there has been a decrease in the application of criminal sanctions against offender of the Immigration Law every year. Article 116 of Law Number 6 Year 2011 concerning Immigration, occupies the position of the most violated each year, as shown on Table 7. 
Table 7. Offender of Article 116 of Law Number 6 Year 2011 concerning Immigration

\begin{tabular}{cc}
\hline Year & Total \\
\hline 2016 & 157 \\
2017 & 195 \\
2018 & 70 \\
\hline
\end{tabular}

Overall, the number of violators of Article 116 of Law Number 6 Year 2011 concerning Immigration did not decrease with certainty, because in 2016 with a total of 157 (one hundred and fifty) people increased to 195 (one hundred and ninety five) people in 2017 and decreased again. in 2018 with a total of 70 (seventy) people. Following data (Table 8) explaines on administrative sanctions imposed by the Directorate General of Immigration throughout Indonesia in Law Number 6 of 2018 concerning Immigration.

Table 8. Administrative Action on Immigration Crime Cases (2016-

\begin{tabular}{|c|c|c|c|c|c|}
\hline \multicolumn{6}{|c|}{ 2018) } \\
\hline No & Form of Enforcement & 2016 & 2017 & 2018 & Total \\
\hline 1 & Deterrence & 1.577 & 1.696 & 3.166 & 6.439 \\
\hline 2 & Stay Permit & 9 & 77 & 689 & 775 \\
\hline & Cancellation & & & & \\
\hline 3 & $\begin{array}{l}\text { Prohibition to be in one } \\
\text { or several certain places }\end{array}$ & 11 & 40 & 88 & 139 \\
\hline & $\begin{array}{l}\text { in the Indonesian } \\
\text { Territory }\end{array}$ & & & & \\
\hline 4 & $\begin{array}{l}\text { Requirement to reside in } \\
\text { a certain place in } \\
\text { Indonesian Territory }\end{array}$ & 1.455 & 1.819 & 1.581 & 4.855 \\
\hline 5 & Charging of expenses & 945 & 1.042 & 1.805 & 3.792 \\
\hline 10 & Deportation & 3.929 & 4.480 & 4.981 & 13.390 \\
\hline & TOTAL & 7.926 & 9.191 & 11.769 & 29.390 \\
\hline
\end{tabular}

Source: Ministry of Law and Human Rights, Directorate General of Immigration

Based on the table above, it can be seen that, the number of Immigration Administration sanctions actions carried out by Immigration Officers from 2016 to 2018 totaled 29,390 (twentynine thousand three hundred ninety) cases, with Administrative Actions sanctions every year as follows:

1. In 2016 the number of immigration administrative sanctions measures was 7,926 (aiming for a thousand nine hundred twentysix) people

2. In 2017 the number of immigration administrative sanctions measures was 9,191 (nine thousand one hundred and ninetyone) people 


\section{A. Bahari}

3. In 2018 the number of immigration administrative sanctions measures was 11. 769 (eleven thousand to hundred and sixtynine) people

The data above shows an increase in the number of Administrative sanctions carried out by Immigration Officers against violators of Law Number 6 of 2011 concerning Immigration each year has increased. Deportation Sanctions are the most imposed sanctions each year, as on Table 9 below.

Table 9. Number of Deportation Sanctions

\begin{tabular}{cc}
\hline Year & Total \\
\hline 2016 & 7,926 \\
2017 & 9,191 \\
2018 & 11,768 \\
\hline TOTAL & $\mathbf{2 8 , 8 8 6}$ \\
\hline
\end{tabular}

From the data presented above, both criminal sanctions and administrative action sanctions can be concluded that from year to year there has been a decrease in criminal sanctions and an increase in the Immigration Administration sanctions action.

Table 10. Ranking of the Top 10 Citizens Subject to Administrative Actions in Law Number 6 of 2018 concerning Immigration

\begin{tabular}{clc}
\hline No & Country & Total \\
\hline 1. & Tiongkok/China & 1.542 \\
2. & Vietnam & 890 \\
3. & Nigeria & 630 \\
4. & Malaysia & 550 \\
5. & Bangladesh & 309 \\
6. & Afghanistan & 304 \\
7. & South Korea & 251 \\
8. & Thailand & 244 \\
9. & India & 212 \\
10. & Philippines & 200 \\
\hline
\end{tabular}

Source: Directorate General of Immigration of Indonesia

From the data above, it can be seen that the enforcement of immigration law in Indonesia with administrative sanctions, PRC citizens are the most legal subjects subject to immigration administrative sanctions in 2018, with a total of 1,542 (one thousand five hundred and forty two) people, and at least 200 (two hundred) Philippines citizens.

The application of the ultimum remedium principle in the Immigration Law has begun to be used as a benchmark for immigration law enforcement 
carried out by immigration officials. This can be seen from the decreasing data on criminal sanctions from year to year and the increasing immigration administrative sanctions. The benchmark for the success of implementing the ultimum remedium principle if the sanctions imposed by immigration officials bring prosperity to the people of Indonesia. Law enforcement must be based on the aim of legal certainty that is just and prosperous which can create a safe, fair, and beneficial climate for community life, both for the community and for the accused and convicted.

In principle, criminal sanctions still adhere to the classical criminal principle (plunder), in practice they cannot create a comfortable, fair, and beneficial climate for community life. The impact of criminal sanctions will result in overcrowding of correctional institutions that exceeds the capacity limit and has resulted in sexual harassment, social demoralization and security in prisons, and there has even been an increase in the quality of criminal acts so that it is often called prison is a high school of crime.

\section{Immigration Law Enforcement in Indonesia}

a) Duties and Functions of Immigration PPNS Investigators

Law enforcement in immigration cases in Indonesia faced many problems, one of is the duties of Civil Servant Investigators (Penyidik Pegawai Negeri Sipil, hereinafter as PPNS) for these crimes. Generally, the legal basis for investigating immigration crimes are:

1) Law Number 6 Year 2011 concerning Immigration

2) Criminal Procedure Code (KUHAP); and

3) Government Regulation No. 31 of 2011 concerning Implementing Regulations of Law Number 6 of 2011 concerning Immigration.

Investigation is a series of actions by an investigator to find and collect evidence, which with that evidence makes clear the criminal act that has occurred in order to find the suspect. ${ }^{89}$ Meanwhile, what is meant by Investigators are Indonesian National Police officers who are at least the rank of Assistant Second Lieutenant Police, or certain civil servant officials, who are at least the rank of Junior Level I (Group II/b) or equivalent, who are given special authority by law to conduct investigations.

PPNS investigators are appointed by the Minister upon the recommendation of the Department in charge of the civil servants or officials appointed and authorized by him. The Minister of Justice before carrying out the appointment, first hears the considerations of the Attorney General and

89 Republic of Indonesia, Law Number 8 of 1981 concerning Criminal Procedure Law (KUHAP), State Gazette of 1981, Supplement to State Gazette Number 3209, Article 1 point 2. 


\section{A. Bahari}

the Head of the Indonesian Police, ${ }^{90}$ in relation to the Immigration PPNS given special authority as an investigator to carry out immigration criminal investigations. ${ }^{91}$

The Authority of Civil Servant Investigators of Immigration is an immigration officer who is authorized by law to carry out investigations of immigration crime. Immigration Officials also form a Foreigner Supervision Team (Tim Pengawasan Orang Asing, hereinafter as Timpora) in the Municipality, District, which helps in providing information about the whereabouts of foreigners so that the immigration as the coordinator in the Team can carry out supervision and prosecution in the event of immigration violations or crimes. To support the supervision of foreigners, it requires community participation to play an active role in providing information and socialization in supervising foreigners in their environment. Timpora consists of Immigration Officers, Police and Military in carrying out their duties, they are required to prioritize their role in Timpora and not have sectoral egos. ${ }^{92}$ In carrying out its functions, PPNS Immigration is authorized to ${ }^{93}$ :

a. Receiving a report or complaint from someone regarding a criminal act

b. Looking for information and evidence

c. Take the first action at the scene

d. Ordering someone to stop a suspect and check the suspect's identification

e. Carry out arrests, detention, finds, and confiscation

f. Checking and confiscating letters

g. Take fingerprints and take a picture of someone

h. Calling people to be heard and examined as suspects or witnesses

i. Bring in the necessary experts in connection with case examination

j. Hold an investigation halt

k. Conduct other actions according to responsible law

In carrying out the investigation process, the Immigration PPNS coordinates with the Indonesian Police Investigators. Evidence for examination of immigration crime in the form of:

1) Evidence as referred to in criminal procedural law

2) Other evidence in the form of information uttered, sent, and received or stored electronically or equally to those evidences

90 Republic of Indonesia, Government Regulation on the Implementation of the Criminal Procedure Code, Article 2 paragraph 5.

${ }^{91}$ Indonesia, Government Regulation Number 27 of 1983 concerning Implementation of the Criminal Procedure Code, State Gazette of the Republic of Indonesia of 1983 Number 3258 , Article 2 points (a) and (b).

92 Okky Chahyo Nugroho, Op.Cit., p. 38.

93 Republic of Indonesia, Law Number 8 of 1981 concerning Criminal Procedure Law (KUHAP), State Gazette of 1981, Supplement to State Gazette Number 3209, Article 7 paragraph 1. 
3) Written provisions from authorized immigration officers.

In carrying out immigration control of foreigners carried out by ${ }^{94}$ :

1) Director General, to carry out supervision

2) Immigration at the Center

3) Head of the Regional Office of the Ministry of Law and Human Rights, to carry out immigration control in the province

4) Head of the Immigration Office, to carry out immigration control in the Regency/City or District; and

5) A designated Immigration Officer or Foreign Service Officer, to carry out immigration control outside the Indonesian Territory.

In order to carry out the function of Immigration, Immigration Officials conduct immigration investigations and immigration security and are authorized ${ }^{95}$ :

1) Obtain information from the public or government agencies

2) Visiting a place or building where information is suspected to be found regarding the whereabouts and activities of foreigners

3) Performing Immigration Intelligence operations; or

4) Safeguarding data and information on Immigration and securing the implementation of Immigration duties.

Implementation of immigration law enforcement in accordance with the rule of law in the form of administrative sanctions and criminal sanctions. There are two things under the authority of PPNS Immigration against violations and crimes in the enforcement of immigration law in Indonesia, namely:

1) Inclusion in the list of Prevention or Prevention

2) Restriction, change, or cancellation of Stay Permit

3) Prohibition of being in one or several certain places in the Indonesian Territory

4) The requirement to reside in a certain place in the Indonesian Territory

5) Charging of expenses; and / or

6) Deportation from Indonesian Territory.

Immigration Administrative Sanctions in the form of Deportation can also be carried out against foreigners who are in the Indonesian Territory for trying to avoid threats and the implementation of punishment in their home country.

The implementation of Criminal Sanctions is carried out against cases of Immigration Crime which by the Immigration PPNS go through a process

94 Jazim Hamidi \& Charles Christian, Hukum Keimigrasian Bagi Orang Asing di Indonesia, Jakarta, Sinar Grafika, 2016, p. 104.

95 Republic of Indonesia, Implementing Regulations for the Immigration Law 


\section{A. Bahari}

with the fulfillment of formal elements, including the Official Report of Investigation, collection of evidence, stipulating a letter of commencement of investigation, then notification of the Police Investigator. After all the files are complete, the Case Files are submitted to the Public Prosecutor through the Police Investigators, then the Police Investigators review the Case Files and if there is insufficient evidence they will be returned to the Immigration Service. Submission of case files is accompanied by submission of the suspect and evidence, then awaits the prosecution process by the public prosecutor and the judicial process to decide whether the defendant is guilty or not and the type of sentence imposed.

For foreigners who have been convicted by the Court and have served their sentences, the Foreigner is handed back to the Immigration for Deportation. While waiting for the deportation process, the foreigner is placed at the Immigration Rudenim. The Deportation process includes completeness of travel documents, return tickets to countries of origin and so on. If the Foreigner is finished in Deportation, the Immigration Law Enforcement process is finished through the judicial process. The period of investigation until the court verdict takes approximately 3 (three) months. ${ }^{96}$

According to Komang, as the Head of the Sub Directorate of Immigration Investigation. In law enforcement if there are violations and crimes in the Immigration Law committed by a Foreigner, PPNS Immigration will coordinate with the Embassy where the Foreigner comes from, while waiting for the Deportation process, if the Foreigner wants to get refugee status, the Immigration will wait for the process to be carried out by The United Nations High Commissioner For Refugees (UNHCR) the time for the verification process is uncertain. ${ }^{97}$

A similar view is in line with the opinion of the Associate External Relations Officer who stated that the verification process carried out by UNHCR is in the form of ${ }^{98}$ :

1) Registration

2) Schedule an in-depth interview process accompanied by a translator who will help the communication process

3) Review, the results of the interview will be examined to determine whether the asylum seeker meets the criteria as a refugee based on the 1951 Convention.

96 Okky Chahyo Nugroho, Op.Cit., p. 32

97 Interview Results with Komang, S.H., M.H., as Head of the Indonesian Immigration Investigation Sub-directorate

98 Results of Interviews with Mitra Salima Suryono, as UNHCR Associate External Relations. 
If the requirements fulfiled, the foreigner gets the status as a Refugee, and if he does not meet the requirements, the foreigner has the right to appeal 1 time to repeat the process. If his asylum request has been rejected twice, the foreigner will be returned to Immigration and Immigration can take Immigration action. In enforcing immigration law, according to the Head of Sub Directorate of Immigration Investigation of the Republic of Indonesia, Komang that there are factors that hinder the process of enforcing the Immigration law:

1) The legal factor itself in Article 75 paragraph 1 which gives Discretion to Immigration Officers as Administrative Officials to determine whether to use the application of administrative sanctions or criminal sanctions in violations or crimes in the Immigration Law

2) The existence of a legal loophole in the Immigration Law makes the Foreigner legal person able to make efforts to resolve cases outside the Immigration legal process

3) Foreigners who enter Indonesia deliberately throw away their official documents and apply for asylum at The United Nations High Commissioner for Refugees (UNHCR) to delay the legal process.

Furthermore, at this point, Author emphasized that the problem here is that there is no clear provision on how long it will take to verify refugee status for foreigners who apply for refugee status by The United Nations High Commissioner for Refugees (UNHCR) until the issuance of refugee status. So, there must be an internal regulation of The United Nations High Commissioner for Refugees (UNHCR) related to this arrangement so that these illegal immigrants are not in detention centers without clear legal certainty.

The factors that cause Immigration Officers to use administrative and criminal sanctions are due to their own legal factors in Article 75 paragraph 1 which gives Discretion to Immigration Officers as Administrative Officials to determine whether to use administrative sanctions or criminal sanctions in violations or crimes in the Immigration Law.

It is necessary to consider the impact of the violations and crimes committed, the author agrees with Prof. Romli Atmasasmita's view which states that aspects of justice and benefits must take precedence over legal certainty so that consciously we have made social welfare the goal of punishment. Affirmed by Prof. Muladi said that the Criminal Justice System in the short term aims to conduct resocialization of criminal offenders, medium term in the form of crime control and long term in the form of social welfare. 
Of course it is very clear that imposing administrative or criminal sanctions needs to be studied in more detail, because the imposition of crimes can have an impact on overcrowded institutions, the costs of each case that are processed in the criminal justice system that are borne by the State, an increase in the quality of criminal acts is often called imprisonment. is a high school crime in the process of socialization in prisons and resulting in sexual harassment and social demoralization.

Nevertheless, it must be clear that the benchmarks for when administrative sanctions and criminal sanctions can be applied must be based on the aim of legal certainty that is just and prosperous which can create a safe, just and beneficial climate of community life for both the community and the accused and convicted. Below will be presented data related to the application of administrative and criminal sanctions immigration handled by Immigration Officers from 2016 to 2018 throughout Indonesia:

\begin{tabular}{ccc}
\hline Year & Total & Type of Enforcement \\
\hline 2016 & 341 & Projustitia \\
2017 & 237 & Projustitia \\
2018 & 145 & Projustitia \\
\hline Total & $\mathbf{7 5 9}$ & \\
\hline
\end{tabular}

From the data above, it can be concluded that the application of criminal sanctions has decreased every year. Data from 2016 to 2018 shows an increase in the number of Administrative sanctions in the form of prevention/cancellation, cancellation of residence permits, restrictions on being in certain places, detention, imposition of burdens and deportations by Immigration Officers against violators of the Immigration Law:

\begin{tabular}{cc}
\hline Year & $\begin{array}{c}\text { Number of } \\
\text { Administrative Actions }\end{array}$ \\
\hline 2016 & 6.729 \\
2017 & 9.191 \\
2018 & 11.769 \\
\hline
\end{tabular}

From the data above, it can be concluded that there is an increase in Administrative sanctions every year. Administrative sanctions in the form of deportation are the most sanctions imposed each year. So, it can be concluded that from year to year there has been a decrease in criminal sanctions and an increase in the Immigration Administration sanctions action.

In the immigration criminal law process carried out by the Immigration PPNS, it will coordinate with the Police investigator, the Attorney General's Office and the Panel of Judges will issue a verdict on the 
accused. Foreigners who have been convicted by the Court after undergoing their sentence will be handed back to the Immigration for the Deportation process, while waiting for the Deportation process, these Foreigners will be included in the Immigration Detention Center.

\section{Handling of Immigration Crime in Indoneisa}

\section{a) Cases of Immigration Law Violators}

Data on asylum seekers and refugees as of September 30, 2018 were 2,904 (two thousand nine hundred four) asylum seekers and 10, 929 (ten thousand nine hundred and twentynine) refugees. If classified based on gender, the number for men is 9,525 (nine thousand five hundred and twentyfive) people and the number of women is 4,308 (four thousand three hundred eight).

There are 30 foreigners as asylum seekers and refugees who entered the State of Indonesia for the period of September 30 2018, consisting of 1,522 asylum seekers in Immigration Detention Centers (one thousand five hundred and twenty two), living in Indonesia independently with personal expenses of 5,145 (five thousand one hundred and forty five) people and asylum seekers and refugees who are in the Community House as many as 7,166 (seven thousand one hundred and sixty six) people.

The number of foreigners who enter Indonesia by air, land and sea, on the grounds of seeking asylum legally and illegally for the 2016-2018 period (as of June 2018) are as follows:

\begin{tabular}{cccc}
\hline Year & Illegal & Legal & Total \\
\hline 2016 & 209 & 13.982 & 14.191 \\
2017 & 275 & 13.428 & 13.703 \\
2018 & 87 & 13.842 & 13.929 \\
\hline
\end{tabular}

Based on the data above, it can be classified based on what instruments are used by foreigners to enter Indonesia. Foreigners seeking asylum legally come to Indonesia by air (plane), land (car) and sea (ship). Meanwhile, those who enter illegally are those who enter in groups by water and enter without official documents.

Become a new challenge for immigration law enforcement. Because in practice foreigners who enter Indonesia without carrying complete documents and declare themselves as asylum seekers without the support of evidence owned by foreigners, the Immigration officer will bring foreigners who enter illegally to Rudemim as a temporary shelter for foreigners who subject to Immigration Administrative Sanctions. It becomes interesting when Foreigners who have been subject to Immigration Administrative Sanctions 


\section{A. Bahari}

in the form of Detention declare themselves as asylum seekers and must undergo the legal process in the criminal justice system and are subject to criminal sanctions.

In addition, there was a tragedy on March 152018 where the International Organization for Migration (IOM) which is an international organization that deals with refugees, the International Organization for Migration (IOM) has stopped some of its financing for asylum seekers in Indonesia, this makes asylum seekers have to wait their legal process at the Immigration Detention Center even though Immigration has issued a Letter of the Director General of Immigration Number IMI-UM.01.01-2827 dated July 30, 2018 regarding the return of Rudenim functions that cannot be occupied by asylum seekers. However, due to budget cuts from the International Organization for Migration (IOM), the refugees remain in the detention center's house.

Another problem that then arises when the process carried out by the United Nations High Commissioner for Refugee (UNHCR) to issue a Refugee letter does not have a minimum limit when the statement is issued. For example, in the case of Besmillah Qasemi and Shaqera Qasemi who entered Indonesia illegally without carrying documents, then they were criminally processed by Immigration officers to make it easier to see the problem of Enforcement of Immigration law as a whole, the authors analyzed 3 (three) District Court decisions.

\section{1) The case of Shaqera Qasemi}

Shaqera Qasemi, who is an Afghan national, has committed a criminal act of immigration due to entering Indonesia without a travel document, as a result of this incident the defendant was legally processed and underwent a judicial process at the Tangerang District Court. Tangerang District Court Decision:

a. State that the Defendant SHAQERA QASEMI has been legally and convincingly proven guilty of committing a criminal act "In the Immigration Midwife".

b. Imposing a sentence against SHAQERA QASEMI with imprisonment of 1 (one) month

c. Sentencing the Defendant to pay a court fee of Rp. 5,000.00 (five thousand rupiah).

\section{2) The case of Besmillah Qasemi}

Bemillah Qasemi is a foreign national from Afghanistan who was detained by the Soekarno Hatta Airport Immigration Officer for not carrying 
travel documents. As a result of his actions, the PPNS Immigration Investigator charged the defendant with Article 116 Jo Article 71 letter b for not carrying out his obligations in the form of carrying Travel Documents.

After an examination was carried out in a trial at the Court, the panel of judges examining the case gave a decision to the defendant in the form of:

a. To declare that the Defendant, BESMILLAH QASEMI, has been legally and convincingly proven guilty of committing a criminal act "in the Immigration Sector"

b. Imposing the defendant BESMILLA QASEMI with imprisonment for 1 (one) month; and

c. Sentencing the Defendant to pay a court fee of Rp. 5000.00 (five thousand rupiah).

The verdict handed down by the Panel of Judges at the Tangerang District Court was lighter than the demands of the Public Prosecutor, namely 2 months in prison. Previously, in his testimony as an expert, Ahmad Sofian, gave his comments at the trial:

"That the conviction of a defendant should be taken as an ultimum remedium to avoid double criminalization of double jeopardy because Article 75 of Law Number 6 Year 2011 concerning Immigration regulates various forms of administrative action that can be implemented in advance, such as detention currently being applied to the accused. Whereas after being detained for a certain time and the defendant still has to be convicted, this according to the expert is a form of double criminalization which is contrary to the principle of double jeopardy (imposing sanctions more than once for the same violation). In criminal law to uphold the principle of ultimum remedium, this case should not be continued until the court stage or at least the Defendant needs to be declared free from various lawsuits because he has imposed an Immigration Administrative Action in the form of a previous detention."

In his consideration the judge gave consideration to the statements of the above Experts:

"That the placement of the defendant in the Immigration Detention Center has been regulated in Law no. 6 of 2011, and cannot be viewed as a crime for someone, placing someone in the Immigration Detention Room is only a temporary shelter due to administrative actions and not for implementing a court decision, that the double jeopardy principle is not known in Indonesian law, because Indonesian law only analyzes the 
principle nebis in idem as stipulated in Article 76 of the Criminal Code, however, placing a person in the Detention Room and finally being sentenced to a sentence cannot be considered that a person has been sentenced twice in the same case, because a person is said to have served a sentence only if he has implemented the verdict as a result of being sentenced. the sentence based on a court decision which has legal force remains in the same case "

According to the Head of the Sub-Directorate of Immigration and Deportation Detention, Jaya Saputra, that Detainees who serve a longer period of detention than court decisions are an issue that has yet to be resolved, as a result of Detention regulations not regulated in the Criminal Procedure Code. The state must pay if the detainee is serving a longer detention period than the unhappy court ruling.

\section{3) Case of Rabie Abderahmad Ayad}

Rabie Abderahmad Ayad, Lebanese nationality has been arrested and later detained by the Bali Regional Police based on the Red Notice issued by the United States Government in the context of the prosecution process in the United States, Rabie Abderahmad Ayad has served 342 (three hundred and forty two) days in detention, as a result there is a request for extradition from the United States government.

Denpasar District Court Preliminary Decision Number 3 / Pid.Pra / 2019 / PN Dps:

In Exception

1. Reject the Respondent's exception

In the Subject of the Case

1. Reject the Petitioners' pretrial petition

2. To charge the Petitioner a nil amount

The main problem is related to the submission of pretrial due to the detention carried out by the respondent (Bali Regional Police) on April 19, 2018, having violated the time of period specified in Law Number 1 of 1979 concerning Extradition. The legal considerations of the Denpasar District Court Judge in the decision stated that:

1) Extension of detention is valid and based on law at the request of US law enforcers in the form of Red Notice Control and Facsimile News from the Head of the National Police International Relations Division Number: NBC-Div HI / Fax / 715 / IV / 2018 dated 17 April 2018;

2) Whereas based on Article 19 paragraph (2) and (3) Law Number 1 Year 1979 concerning Extradition, that the issuance of an order to arrest and 
or detain someone who is requested to be extradited is carried out based on the provisions of the Indonesian Criminal Procedure Code, and deviating from the provisions of the applicable Indonesian Criminal Procedure Code, those who commit extraditable crimes under this law may be subject to detention;

3) Article 25 stipulates that if the crime is a crime which is subject to detention according to the Indonesian Criminal Code and the provisions referred to in Article 19 paragraphs (2) and (3) and a request for detention is submitted by the requesting country, the person is subject to detention;

4) Terms for Extension of Detention In Article 35 paragraph 2 of Law Number 1 Year 1979 Concerning Extradition, the period of detention as referred to in Article 34 letter (b) can be extended each time up to 30 (thirty) days. Extension can only be done if:

a. The absence of a court order regarding extradition requests

b. Information is required by the Minister of Justice as referred to in Article 36 paragraph (3)

c. Other countries have also requested extradition and the President has not yet made a decision

d. The request for extradition has been granted, but cannot yet be implemented

5) The conditions for extension of detention in Article 35 paragraph (2) above are not cumulative in nature, but are alternative in nature, so that if one of these conditions is met, then an extension of detention can be carried out, as in detention in this case, against a request for extradition by The Petitioning State has not yet received a court order, so the detention of the Petitioner (Extradition Respondent) can be extended based on Article 35 paragraph (2) letter a above

Based on the testimony of expert Eva Achjani Zulfa basically explains the following:

1) Referring to Law Number 1 of 2006 concerning Reciprocal Legal Assistance in Criminal Matters (MLA Law), the spirit of case handling based on the MLA Law is a speedy trial which refers to a widely agreed norm, namely the due process of the law which also outlined in the Criminal Procedure Code as the principle of speed, simplicity and low cost

2) Whereas based on the optional protocol of the Convention Against Torture (CAT), an extension of detention can only be carried out at the request of the requesting country because prolonged detention for too long is a form of torture or torture 


\section{A. Bahari}

3) Whereas based on the provisions of Article 21 of the Extradition Law linked to the Convention Against Torture, if the period of detention is about to expire and the country requesting extradition cannot provide sufficient reasons for the extension of the detention in question, then the detained person must be released by law

4) Whereas the word "every time" in Article 35 paragraph (1) of the Extradition Law if it is translated as extendable for more than 1 (one) time it will be contrary to the principle of due process of the law

5) Whereas if the word "every time" in Article 35 paragraph (1) of the Extradition Law is translated as can be extended more than 1 (one) time, then:

(1) A request for an extension of detention must be at the request of the Requesting State; and

(2) There must be a strong reason for requesting an extension of the detention

6) Based on the provisions of Article 35 jo. Article 21 of the Extradition Law, for legal subjects whose extradition documents have not been completed, the state must immediately determine the status of such legal subjects, the provisions of Article 35 jo. Article 21 of the Extradition Law, the prosecutor's office is given the authority to apply for an extension of detention to the District Court at the request of the requesting country

7) The period of detention for 350 days is too long, and the state must confirm the status of the detained person as soon as possible

8) Yes, it should be released first, and if you really want to be detained, then the detention should be continued, of course, a new procedure, a new process, not then basing that authority on a single act that is actually without authority, so administratively when we talk about Law Number 30 of 2016 concerning Government Administration, it is already a maladministrative act.

According to the author, agree with the opinion of expert Eva Achjani Zulfa, based on Article 34 letter (b) of the Extradition Law states that a detention ordered under Article 25 is revoked, if it has been running for 30 days unless it is extended by the Court at the request of the Prosecutor.

Article 25 states that:

If the crime is a crime which is subject to detention according to the Criminal Procedure Code of the Republic of Indonesia and the provisions referred to in Article 19 paragraph (2) and (3) and a request for detention is submitted by the requesting country, the person is subject to detention. 
Article 19 states that:

(1) The request for detention shall be submitted by the competent authority of the requesting country to the Chief of Police of the Republic of Indonesia or the Attorney General of the Republic of Indonesia through Interpol Indonesia or through diplomatic channels or directly by post or telegram.

(2) Arrangement of an order to arrest and or detain a person concerned is carried out based on the provisions in the Indonesian Criminal Procedure Code, unless otherwise stipulated as provided in paragraph (3).

(3) Deviating from the provisions of the applicable Indonesian Criminal Procedure Code, those who commit crimes that can be extradited under this Law may be subject to detention.

According to the author, based on the formulation of the article above, detention can be extended if there is a request for detention from the requesting State. In this case the new extradition documents were sent by the United States government on 11 February. This means that the extension of detention should only be carried out after February 11, based on the new extradition documents received by the Ministry of Law and Human Rights of the Republic of Indonesia and have been declared to have met the requirements and requests for extradition from the United States Government for the person concerned has received approval from the President of the Republic of Indonesia so that the extradition process of the subject can be implemented on February 11, 2019.

Based on Article 21:

In the event that the person concerned is detained, the person is released by the Attorney General of the Republic of Indonesia or the Chief of Police of the Republic of Indonesia if the time deemed sufficient since the date of detention, the President through the Minister of Justice of the Republic of Indonesia does not accept the extradition request along with the documents as referred to in Article 22. from the requesting country.

Article 22 states that:

(1) A request for extradition will only be considered if it meets the requirements as mentioned in paragraph (2), paragraph (3), and paragraph (4).

(2) A letter requesting extradition must be submitted in writing through diplomatic channels to the Minister of Justice of the Republic of Indonesia to be forwarded to the President.

(3) A letter requesting extradition for a person whose extradition is requested to serve a sentence must be accompanied by: 
a. Original sheets or authentic copies of court decisions in the form of convictions that already have definite legal force

b. Information needed to determine the identity and nationality of the person requested for extradition

c. Original sheet or authentic copy of the detention warrant issued by the competent authority of the requesting country.

(4) A letter requesting extradition for a person suspected of committing a crime must be accompanied by:

a. Original sheet or authentic copy of the detention warrant issued by the competent authority of the requesting country

b. Description of the crime for which extradition is requested, stating the time and place where the crime was committed, accompanied by the necessary written evidence

c. The text of the legal provisions of the requesting Country which is violated, or this is not possible, the content of the law being applied

d. Witness statements under the sumaph regarding their knowledge of the crimes committed

e. information needed to determine the identity and nationality of the person requested for extradition

f. Request for confiscation of evidence, if any and needed.

The author also agrees with expert Eva Achjani Zulfa, who states that if the provisions of Article 21 of the Extradition Law are linked to the Convention Against Torture, if the period of detention has ended and the country requesting extradition cannot provide sufficient reasons for the extension of the detention in question, then the person who being detained must be released by law, so the existence of prolonged detention that is too long without legal certainty is a form of torture or torture.

Whereas according to the author, this problem will be resolved quickly, simply and at low cost if it is resolved in coordination with the Immigration Officer, in which Article 13 paragraph (1) letter (h) of Law Number 6 of 2011 concerning Immigration that Immigration officials refuse foreigners to enter Indonesian territory in the event that the foreigner is included in the list of wanted persons to be arrested from a foreign country. Article 13 paragraph (2) also confirms that foreigners who are refused entry as intended in paragraph (1) are placed under temporary supervision awaiting the return process concerned. It is emphasized in Article 75 paragraph 3 that immigration measures in the form of deportation can also be carried out against foreigners who are in the territory of Indonesia for trying to avoid threats and the implementation of punishment in their home country. 
The author sees that to resolve this case so that it can be resolved quickly, simply and at low cost without the existence of a long detention, the Indonesian Police should coordinate with Immigration Officers regarding the process of Deportation of Foreigners in this case.

The author analyzes 2 (two) decisions of the Tangerang District Court Number 01 / Pid.S / 2018 / PN.TNG and Decision Number 02 / Pid.S / 2018 / PN.TNG on the basis that these 2 (two) decisions are cases similar to The same charges are charged with Article 116 Jo Article 71 letter b of Law Number 6 of 2011 concerning Immigration:

Every Foreigner who is in the Territory of Indonesia is obliged to show and submit Travel Documents or Stay Permits in his possession if requested by the Immigration Officer on duty in the framework of immigration control. If he does not violate, he will be punished with a maximum imprisonment of 3 (three) months or a maximum fine of Rp. 25,000,000.00 (twentyfive million rupiah).

The verdict of the Panel of Judges in these two cases imposes a 1 (one) month imprisonment. However, one of the judges in one of the decisions Number 02 / Pid.S / 2018 / PN TNG expressed a different view from the other judges (Dissenting Opinion). Member Judge II Edy Purwanto, stated that based on Article 13 paragraph 3 and Article 20 paragraph 3 of Presidential Regulation Number 125 of 2016 concerning Handling of Refugees from Abroad, which states that if there are foreigners who claim to be refugees, the Immigration Detention Center officials coordinate with The UN through the Office of the High Commissioner for Refugees in Indonesia (UNHCR), of course, means that the foreigner must first determine his status, whether as a refugee or not, which will be used as a reference for the next step in the process. If, this provision is violated / not carried out, the case handling procedure is flawed. The prosecutor's demands must be declared unacceptable.

According to Mitra Salima Suryono as Associate External Relations / PI Officer of The United Nations High Commissioner For Refugees (UNHCR) stated that regarding foreigners who enter Indonesian Territory without official documents such as a passport, if the foreigner declares that he wants to seek asylum, it will be allowed entry into Indonesia based on Presidential Regulation Number 125 of 2016 concerning Handling of Refugees from Abroad, regardless of whether foreigners have documents or not, it should be directed to The United Nations High Commissioner For Refugees (UNHCR) to determine their status. If the determination of the status is obtained 


\section{A. Bahari}

information that the person is a refugee, then it is permissible to stay in Indonesia for a long time. The residence permit will not be a problem in accordance with the Regulation of the Director General of Immigration 2016. However, if after the status of the UNHCR has been determined the foreign person is not a refugee, then it can be processed by the Immigration authorities in accordance with the Immigration Law as Illegal Immigrant.

According to Paulina as the Protection Associate of The United Nations High Commissioner For Refugees (UNHCR), the foreigner who has the status of a refugee will immediately find a solution by The United Nations High Commissioner For Refugees (UNHCR) with several long-term options:

1. Repatriation when the conflict in the country has ended

2. If any third country is willing to accept their arrival

If these two options have not been achieved, The United Nations High Commissioner for Refugees (UNHCR) will provide solutions, for example preparing refugees for their future, including the obligation to provide assistance in the form of accommodation, education, food, medical. The United Nations High Commissioner for Refugees (UNHCR) partners with IOM, JRS, Dompet Dhuafa in helping refugees. For foreigners who enter detention, if they have obtained the status of a Refugee, then The United Nations High Commissioner for Refugees (UNHCR) will provide a certificate to the Detention Center stating that the person concerned already has Refugee status. Immigration with cooperatives to free the Refugee if accommodation is provided if they have been released from Detention. The problem is the issuance of the long refugee status and the limited process of accommodation, which can provide accommodation in the form of a place to live for refugees, if accommodation is available, usually Immigration will release the related Refugee as long as there is status from The United Nations High Commissioner For Refugees (UNHCR) and accommodation that has been provided. That is why the asylum seekers or refugees are detained in detention centers for longer.

According to Paulina, in this case, the asylum seeker has been undergoing detention for 3 (three) months and was sentenced to imprisonment by the panel of judges for 1 (one) month. The United Nations High Commissioner for Refugees (UNHCR) believes that asylum seekers should not be convicted if it is based on a Presidential Decree. Immigration when they find out that someone is looking for Asylum, Immigration should coordinate with The United Nations High Commissioner for Refugees (UNHCR) and The United Nations High Commissioner for Refugees (UNHCR) to carry out the registration process. 
According to the author that should be in cases involving foreigners entering Indonesian territory and declaring themselves as asylum seekers or refugees, Immigration officials must first coordinate with the United Nations High Commissioner For Refugees (UNHCR) to determine the status of foreigners, whether they are true asylum seekers. or not. If the United Nations High Commissioner For Refugees (UNHCR) has issued a letter prohibiting that the foreigner is not a refugee then he will be subject to administrative sanctions or criminal sanctions in the Immigration Act, in accordance with the provisions of Article 13 paragraph (3) of Presidential Regulation No. 1252016 concerning the Handling of Refugees from Abroad which states that:

"In the event that there are foreigners who claim to be refugees, officials of the Immigration Detention Center coordinate with the United Nations through the Office of the High Commissioner for Refugees in Indonesia."

The factors that influence the enforcement of the Immigration Law in Indonesia include:

1. Law enforcement factors:

a. namely the parties who are directly involved in the field of immigration law enforcement lack of coordination with international agencies such as UNHCR for foreigners who claim to seek asylum when entering Indonesia without carrying legal documents. This is because immigration officials have not been able to provide legal sanctions before the status of UNHCR is confirmed.

b. The flight time of the refugee status from UNHCR has not been regulated so that the Immigration Officer cannot do the Deportation because it will violate the principle of Non-Penalty.

2. In the author's view that the action of the Immigration Officer placing the defendant in the Detention House will have an overcrowded impact in the Immigration Detention Center, and the Immigration official's policy of placing foreigners who are placed in the Immigration Detention Center for a certain time and still have to be criminalized, this is a form of double criminalization which is contrary to the double jeopardy principle (imposing sanctions more than once for the same offense) in criminal law. To uphold the principle of Ultimum Remedium and double jeopardy in criminal law, the application of administrative sanctions in the form of deportation and deterrence is a good solution for immigration law enforcement because of its fast nature without going through a criminal justice process. 
Decision Number 3 / Pid.Pra / 2019 / PN Dps, with the defendant Rabie Abderahman Ayad a Lebanese citizen. The author agrees with expert Eva Achjani Zulfa, who states that if the provisions of Article 21 of the Extradition Law are connected with the Convention Against Torture, if the period of detention has ended and the country requesting extradition cannot provide sufficient reason for the extension of the detention in question, then the person who being detained must be released by law, so the existence of prolonged detention that is too long without legal certainty is a form of torture or torture.

Whereas according to the author, this problem will be resolved quickly, simply and at low cost if it is resolved in coordination between the Police and Immigration Officials because Immigration Officers have the authority to refuse foreign citizens who are included in the list of wanted persons to be arrested from a foreign country as regulated in Article 13 paragraph (1) letter (h) of Law Number 6 Year 2011 concerning Immigration.

Immigration officials can also carry out Immigration Control while waiting for the repatriation process concerned based on Article 13 paragraph (2) of Law Number 6 Year 2011 concerning Immigration. Immigration Officers can also provide administrative sanctions in the form of deportation as regulated in Article 75 paragraph 3 of Law Number 6 of 2011 concerning Immigration.

The author sees that the resolution of this case can be resolved quickly, simply and at low cost without the existence of a long detention, so the Indonesian Police should coordinate with Immigration Officers regarding the Deportation process for Foreigners so that the case is not complicated and has deprived the independence of foreigners on this case.

\section{Conclusion}

This study concludes that, simply by implementing administrative sanctions in the form of deportation and fines will complete the Immigration legal process quickly, simply and at low cost and applying relatively high fines can provide benefits to the state, then that is where the benchmark for the principle of ultimate remedium can be applied in the Law. Number 6 of 2011 concerning Immigration. Then, the application of administrative sanctions and criminal sanctions can be applied to all violations and crimes in Law Number 6 of 2011 concerning Immigration, except for victims of trafficking and people smuggling. In addition, it must be seen the impact of the violations and crimes that occurred, if the consequences of these crimes or violations 
were disturbing to the public. Then criminal sanctions can be applied, Enforcement of immigration law both Criminal and Administrative is the authority of the Discretionary Office of Immigration Officers as Administrative Officials to provide criminal or administrative sanctions, however, on the other hand due to this great authority Immigration officials must also be careful because in terms of application administrative and criminal sanctions actions will be an opening for negotiations for violators of the Immigration Law with Immigration Officials.

\section{E. Acknowledgments}

Author would like to express the thakfullness to all parties supported direct or indirectly to this research, especially Immigration Office of Indonesia and UNHCR. Author also would like to thank to Faculty of Law, Universitas Negeri Semarang, especially to Indonesian Journal of Advocacy and Legal Services.

\section{F. Declaration of Conflicting Interests}

The authors state that there is no potential conflict of interest in the research, authorship, and/or publication of this article.

\section{G. Funding}

None.

\section{H. References}

Abidin, A. Z. (1987). Asas-Asas Hukum Pidana Bagian Pertama. Bandung: Alumni.

Agustina, I., Amanwinata, R., \& Affandi, H. (2017). Politik Hukum Imigrasi Nasional Pasca Terbentuknya Masyarakat Ekonomi ASEAN. Jurnal Pena Justisia: Media Komunikasi dan Kajian Hukum, 17(2), 59-69.

Anwar, A. (1984). "Perbedaan Penahanan Yang Dilakukan Oleh Pihak Kepolisian Dengan Penahanan Yang Dilakukan Oleh Pihak Imigrasi”, Thesis, Universitas Indonesia.

Apeldoorn, V. (2015). Pengantar Ilmu Hukum. Jakarta: Balai Pustaka.

Arief, B. N. (2003). Kapita Selekta Hukum Pidana. Bandung: Citra Aditya Bhakti.

Atmasasmita, R. (2017). Rekonstruksi Asas Tiada Pidana Tanpa Kesalahan Geen Straf Zonder Schuld. Jakarta: Gramedia Utama. 
BPHN. (2015). Naskah Akademik Rancangan Undang-Undang Tentang Kitab Undang-Undang Hukum Pidana (KUHP). Jakarta: Badan Pembinaan Hukum Nasional.

Ditha, A., Diamantina, A., \& Soemarmi, A. (2016). Pelaksanaan Deportasi Orang Asing di Indonesia Berdasarkan Undang-Undang Nomor 6 Tahun 2011 Tentang Keimigrasian (Studi Kasus Kantor Imigrasi Jakarta Timur). Diponegoro Law Journal, 5(2), 1-14. Retrieved from https://ejournal3.undip.ac.id/index.php/dlr/article/view/10766

Hamidi, J., \& Charles, C. (2016). Hukum Keimigrasian Bagi Orang Asing di Indonesia. Jakarta: Sinar Grafika.

Hardjon, M.P. (2010). Pengantar Hukum Adminstrasi Indonesia. Yogyakarta: Universitas Gajah Mada.

Hamzah, A. (1995). Delik-Delik Tersebar Di Luar KUHP. Jakarta: PT Pradnya Paramita

Hamzah, A. (2015). Pre-Trial Justice Discretionary Justice Dalam KUHAP Berbagai Negara. Jakarta: Sinar Grafika.

Saputra, J. (2018a). Data Pencari Suaka dan Pengungsi di Seluruh Indonesia Periode September 2018. Jakarta: Direktorat Jenderal Imigrasi

Saputra, J. (2018b). Peran Imigrasi dalam Pengawasan Terhadap Pencari Suaka dan Pengungsi di Indoensia. Jakarta: Diretktorat Jenderal Imigrasi.

Karni, K. (1950). Ringkasan Tentang Hukum Pidana. Jakarta: Balai Buku Indonesia.

Lamintang, P.A.F. (1997). Dasar-Dasar Hukum Pidana Indonesia. Bandung: PT. Citra Aditya Bakti.

Low, C. C., \& Mokhtar, K. S. (2017). Deportation Turn in Malaysia: Expansion, Discourse, and Practice. Journal of Population and Social Studies [JPSS], 25(2), 147-166.

Mamudji, S., \& Soekanto, S. (1999). Penelitian Hukum Normatif: Suatu Tinjauan Singkat. Jakarta: Rajawali Pres.

Marzuki, M. P. (2014). Penelitian Hukum. Jakarta: Kencana Prenadamedia.

Muladi, M. (1995). Kapita Selekta Hukum Pidana. Semarang: Badan Penerbit UNDIP.

Moeljatno, M. (1955). Perbuatan Pidana dan Pertanggungan Jawab dalam Hukum Pidana. Yogyakarta: Gajah Mada University Press.

Nugroho, O. C. (2016). Implementasi Projustitia Terhadap Pengawasan Orang Asing. Jakarta: Badan Penelitian dan Pengembangan Hukum dan HAM Kementrian Hukum dan HAM RI.

Othman, M. B. B. (2016). Illegal Immigrant Issue in Malaysia: A Review from An Islamic Perspective. South East Asia Journal of Contemporary Business, Economics and Law,10(4), 33-36. Retrieved from https://www.seajbel.com/wp-content/uploads/2016/09/K10_64.pdf

Pujirahayu, E. W. (2017). Pemikiran Hukum Spritual Pluralistik. Yogyakarta: Thafa Media.

Prodjodikoro, W. (2003). Asas-Asas Hukum Pidana di Indonesia. Bandung: PT Refika Aditama. 
Raharjo, S. (1991). Ilmu Hukum. Bandung: PT. Citra Aditya Bakti.

Rosmawati, R. (2015). Perlindungan terhadap Pengungsi/Pencari Suaka di Indonesia (sebagai Negara Transit) menurut Konvensi 1951 dan Protokol 1967. Kanun Jurnal Ilmu Hukum, 17(3), 457-476.

Sanusi, A. (2017). Penegakan Hukum Terhadap Tindak Pidana Penyalahgunaan Izin Tinggal Keimigrasian (Studi Kantor Imigrasi Kelas I Bandar Lampung). Fiat Justisia: Jurnal Ilmu Hukum, 10(2), 388-412. DOI: https://doi.org/10.25041/fiatjustisia.v10no2.676

Santoso, I. (2007). Perspektif Imigrasi Dalam United Nation Convention Against Transnational Organized Crime. Jakarta: Perum Percetakan Negara.

Sinatra, C. F. (2008). "Analisa Yuridis Penerapan Asas Peradilam Sederhana, Cepat dan Biaya Ringan Dalam Tindak Pidana Yang Tercakup Dalam Beberapa Kompetensi Relatif Pengadilan (Studi Kasus: Tindak Pidana Penipuan Atas Nama YBB)", Thesis, Universitas Indonesia.

Sihombing, S. (2009). Hukum Imigrasi. Bandung: Nuansa Aulia.

Sjahriful, H. A. (1993). Memperkenalkan Hukum Keimigrasian. Jakarta: Ghalia Indonesia.

Subekti, R. (1989). Hukum Acara Perdata. Bandung: Bina Cipta.

Soekanto, S. (2014). Faktor-faktor yang Mempengaruhi Penegakan Hukum. Jakarta: PT Raja Grafindo Persada.

Soemantri, R. H. (1998). Metode Penelitian Hukum dan Jurimateri. Jakarta: Ghalia Indonesia.

Syahrin, M. A. (2018). The Immigration Crime and Policy: Implementation of PPNS Authorities on Investigation. JILS (Journal of Indonesian Legal Studies), 3(2), 175-194. https://doi.org/10.15294/jils.v3i02.27512

Tirtaamidjaja, M.H. (1955). Pokok-Pokok Hukum Pidana. Jakarta: Fasco.

Utrecht. E. (1958). Hukum Pidana 1. Jakarta: Balai Buku Indonesia

Van Schravendjik, H.J. (1956). Buku Pelajaran Tentang Hukum Pidana Indonesia. Jakarta: Balai Buku Indonesia.

Zaidan, A. (2015). Menuju Pembaharuan Hukum Pidana. Jakarta: Sinar Grafika.

\section{Laws and Regulation, Legal Documents}

Republic of Indonesia. (2011). Law Number 6 of 2011 concerning Immigration. Stateg Gazette of Republic of Indonesia of 2011 Number 5216. [Undang-Undang Nomor 6 Tahun 2011 tentang Keimigrasian Lembaran Negara Republik Indonesia Tahun 2011 Nomor 5216].

Republic of Indonesia. (1981). Law Number 8 of 1981 concerning Criminal Procedure Law (KUHAP), Year 1981, State Gazette of 1981, Supplement to State Gazette Number 3209. [Undang-Undang Nomor 8 Tahun 1981 tentang Hukum Acara Pidana (KUHAP), Tahun 1981, Lembaran Negara Tahun 1981, Tambahan Lembaran Negara Nomor 3209].

Republic of Indonesia. (1946). Law Number 1 Year 1946 concerning Criminal Law Regulations (KUHP), Year 1946, State Gazette Year 1946. 
[Undang-Undang Nomor 1 Tahun 1946 Tentang Peraturan Hukum Pidana (KUHP), Tahun 1946, Lembaran Negara Tahun 1946].

Republic of Indonesia. (2009). Law Number 48 of 2009 concerning Judicial Power, State Gazette of 2009 Number 157. [Undang-Undang Nomor 48 Tahun 2009 Tentang Kekuasaan Kehakiman, Lembaran Negara Tahun 2009 Nomor 157].

Republic of Indonesia. (1979). Law Number 1 of 1979 Concerning Extradition, State Gazette of the Republic of Indonesia Number 3130. [UndangUndang Nomor 1 tahun 1979 Tentang Ekstradisi, Lembaran Negara Republik Indoensia Nomor 3130].

Republic of Indonesia. (2006). Law Number 1 of 2006 concerning Mutual Legal Assistance in Criminal Matters, State Gazette of the Republic of Indonesia of 2006 Number 18. [Undang-Undang Nomor 1 Tahun 2006 Tentang Bantuan Timbal Balik Dalam Masalah Pidana, Lembaran Negara Republik Indonesia Tahun 2006 Nomor 18].

Republic of Indonesia. (2016). Presidential Regulation Number 21 of 2016 concerning Visit Visa Free, State Gazette of the Republic of Indonesia of 2016 Number 44. [Peraturan Presiden Nomor 21 Tahun 2016 tentang Bebas Visa Kunjungan, Lembaran Negara Republik Indonesia Tahun 2016 Nomor 44].

Republic of Indonesia. (1983). Government Regulation Number 27 of 1983 concerning Implementation of the Criminal Procedure Code, State Gazette of the Republic of Indonesia of 1983 Number 3258. [Peraturan Pemerintah Nomor 27 Tahun 1983 Tentang Pelaksanaan Kitab Undang-Undang Hukum Acara Pidana, Lembaran Negara Republik Indonesia Tahun 1983 Nomor 3258].

Republic of Indonesia. (2015). Draft Bill of Procedural Criminal Code of 2015. Republic of Indonesia. (2016). Government Regulation Number 125 of 2016 concerning Handling of Refugees from Abroad, State Gazette of the Republic of Indonesia of 2016 Number 368. [Peraturan Pemerintah Nomor 125 Tahun 2016 tentang Penanganan Pengungsi Dari Luar Negeri, Lembaran Negara Republik Indonesia Tahun 2016 Nomor $368]$.

Japan. (1951). Immigration Control and Refugee Recognition Act, Cabinet Order No. 319 of October 4, 1951. Available on http://www.immimoj.go.jp/english/newimmiact/pdf/RefugeeRecognitionAct01.pdf

[Japanese version: 出入国管理および難民認定法 (Shutsunyūkoku kanri oyobi nanmin nintei-hō), available on https://elaws.egov.go.jp/search/elawsSearch/elaws_search/lsg0500/detail?lawId=326 CO0000000319].

Malaysia. (1959). Immigration Act 1959/63, available on https://www.imi.gov.my/portal2017/index.php/en/main-services/entryrequirements-into-malaysia/offences-frequently-committed-byforeigners.html 
Malaysia. (1966). Passports Act 1966, available on http://www.agc.gov.my/agcportal/uploads/files/Publications/LOM/EN/ Act\%20150.pdf

Singapore. (1959) Immigration Act, 1959, available on https://sso.agc.gov.sg/Act/IA1959

\section{Court Judgements}

Putusan Pengadilan Negeri Tangerang Nomor 01/Pid.S/2018/PN. TNG.

Putusan Pengadilan Negeri Tangerang Nomor 02/Pid.S/2018/PN. TNG.

Putusan Praperadilan Pengadilan Negeri Denpasar Nomor 3/Pid.Pra/2019/PN Dps

Surat Tuntutan Kejaksaan Negeri Kota Tangerang Nomor Reg. Perkara: PDM-493/TNG/7/2018

Surat Tuntutan Kejaksaan Negeri Kota Tangerang Nomor Reg. Perkara: PDM-492/TNG/7/2018

\section{Online Sources}

Badan Statistik Nasional, Jumlah Orang Asing Yang Masuk Negara Indonesia, https://www.bps.go.id/subject/16/pariwisata.html\#subjekViewTab1, accessed on 4 April 2019.

BBC, "Donald Trump: Mexico will pay for wall, '100\%"'. BBC-news. Dikutip dari http://www.bbc.com/news/election-us2016-37241284, accessed on 16 March2017.

CNN Indonesia, Warga Negara Indoenesia merupakan pelanggar Keimigrasian terbanyak di Malaysia, https://www.cnnindonesia.com/internasional/20190213135232-106368879/wni-disebut-terbanyak-langgar-imigrasi-malaysia, accessed on 27 March 2018.

Direktorat Jenderal Imigrasi, Sejarah Direktorat Jenderal Imigrasi,http://www.imigrasi.go.id/index.php/profil/sejarah\#\%E2\%80 \%A2-era-revolusi-kemerdekaan, accessed on 19 February 2019.

Gregorius Aryodamar P, "Pencari Suaka di Kebon Sirih Dipindahkan ke Kalideres, Ini Alasannya", https://today.line.me/ID/pc/article/G1PpNy?utm_source=washare, accessed on 12 July2019

Kyodo, "More Illegal Immigrants Put Back In Detention After Release In Japan", https://english.kyodonews.net/news/2018/02/ba5ba9227d83more-illegal-immigrants-put-back-in-detention-after-release-injapan.html, accessed on 24 February 2019.

National Geographic Indonesia. "Dinding Perbatasan Amerika Serikat dan Meksiko Sudah Ada, dan Kami Mengunjunginya", National Geographic, http://nationalgeographic.co.id/berita/2017/01/dindingperbatasan-amerika-serikatdan-meksiko-sudah-ada-dankamimengunjunginya, accessed on 6 April 2017. 


\section{A. Bahari}

Pitoko, R. A. (2017) "Donald Trump Bangun Tembok Perbatasan ASMeksiko", Online News KOMPAS, https://properti.kompas.com/read/2017/01/27/070000521/donald.trum p.bangun.tembok.perbatasan.as-meksiko.?page=all, accessed on July $12,2019$.

Shabad, R. (2017). "No, Trump's victory was not the biggest Electoral College win since Reagan", Online News CBS News, https://www.cbsnews.com/news/no-trumps-victory-was-not-thebiggest-electoral-college-win-since-reagan/, accessed on 12 July 2019

TIME, "Here's Donald Trump's Presidential Announcement Speech". Time.com. http://time.com/3923128/donald-trumpannouncementspeech/, accessed on 12 July 2019.

The White House, "Executive Order Protecting the Nation from Foreign Terrorist Entry into The United States". https://www.whitehouse.gov/the-pressoffice/2017/01/27/executiveorderprotecting-nation-foreign-terrorist-entryunited-states, accessed on 12 July 2019.

\section{Personal Interviews}

Mr. Jaya Saputra, S.H, M.H., as Head of Sub-directorate of Immigration Detention and Deportation of the Directorate General of Immigration of the Republic of Indonesia on December 17, 2018.

Mr. Komang, S.H., M.H., as Head of the Indonesian Immigration Investigation Sub-directorate on January 29, 2019.

Mr. Dilan, S.H., M.H., As Head of the Sub-Directorate for Immigration Enforcement of the Republic of Indonesia on January 29, 2019.

Dr. Ahmad Sofian, S.H., M.A, as an academic from Bina Nusantara University on February 21, 2019.

Mitra Salima Suryono, As UNHCR Associate External Relations, on 20 December 2018.

Ziko Junius Fernando, S.H., M.H., CIL, as an Academician from Palembang University on January 21, 2019. 